\title{
A „túl elméleti” tőzsdeügynök: David Ricardo és az Alapelvek kétszáz éve
}

\begin{abstract}
A tanulmány eredetileg Ricardo Principles of Political Economy and Taxation címü müve új magyar kiadásának bevezetőjeként jelent meg. Az eredeti megjelenésének 200. évfordulójára kiadott kötet bevezető tanulmánya áttekinti Ricardo életét, bemutatja rendkívül sikeres tőzsdeügynöki müködését, majd összefoglalja első, a pénzzel és a jegybanki politikával foglalkozó írásait. Ezt követi magnum opusának és más írásainak, parlamenti beszédeinek és levelezésének elemzése, képet adva arról a szerteágazó életmüről, amely átfogta a korabeli politikai gazdaságtan egészét, benne az elosztás és az érték általa különösen fontosnak tartott problémáit. Ricardo müve megjelenése óta egyaránt kapott elismerö és magasztaló méltatásokat, valamint éles kritikákat. A cikk felvázolja a recepció két évszázadának főbb mozzanatait, a joggal vagy vitathatóan rá hivatkozó vagy nevéhez kapcsolt, ma is aktuális közgazdasági irányzatok és koncepciók - a komparatív költségek elmélete, a „ricardói ekvivalencia” és a „ricardói vétek” stb. - legfontosabb jellemzőit.* Journal of Economic Literature (JEL) kód: B12, B31.
\end{abstract}

„Napjainkban, midőn a gazdasági élet nevezetes átalakuláson megy keresztül, különös súlyt fektetek arra, hogy Ricardónak, a gazdasági szabadság nagy elöharcosának nézetei nálunk is minél szélesebb körben elterjedjenek.” (Láng [1891] V. o.) 1891-ben ezzel a bevezető mondattal bocsátotta az olvasók elé David Ricardo főmüve, az 1817 áprilisában megjelent Principles of Political Economy magyar kiadását a fordító, Láng Lajos. A könyv jelentőségét méltató rövid előszó Ricardo másik fó érdemének „az első összefüggő rendszeres elmélet megteremtését” tartotta, őt tekintette a közgazdaságtudomány „legelvontabb gondolkozójának (...), legkérlelhetetlenebb logikusának”

* A tanulmány David Ricardo A politikai gazdaságtan és az adózás alapelvei - Válogatás egyéb irásokból és parlamenti beszédekböl címü, a Napvilág Kiadó által megjelentetett kötet (a továbbiakban Ricardo [2017a]) bevezetőjének néhány pontban kiegészített változata. A „túl elméleti” Ricardo önjellemzése egy Malthusnak írt levelében (Ricardo [1913] 100. o., [1951-1973] VI. köt. 295. o.).

Itt és a továbbiakban a Ricardo-összkiadás hivatkozása: Ricardo [1951-1973], a Malthusnak írt levelek esetében a magyar kiadást is és az összkiadást is szerepeltetjük: Ricardo [1913], [1951-1973].

Madarász Aladár emeritus kutató, MTA KRTK KTI, egyetemi magántanár, BCE (e-mail: madarasz. aladar@krtk.mta.hu).

A kézirat első változata 2018. április 8-án érkezett szerkesztőségünkbe.

DOI: http://dx.doi.org/10.18414/KSZ.2018.5.449 
(uo. IX. o.). Szinte ugyanezeket a szavakat használta a magyar kiadás előtt két évvel megjelent francia Ricardo-fordítás is: „a könyv megjelenése esemény volt (...), úgy tűnt, hogy a közgazdaságtan tudománya először került kifejtésre" (Beauregard [1889] XX. o.). A francia Paul Beauregard idézte (s talán Láng Lajos is ismerte) az angol romantika egyik leghíresebb esszéjét - Thomas de Quincey: Egy angol ópiumevő vallomásait -, amely elragadtatott hangon számolt be arról a csodálatról, melyet „e mélységesen okos könyv” olvasásakor érzett. Számára Ricardo „a tudomány nagy törvényhozója” volt, aki „a törvényszerüségeket magából az értelemből (...) vezette le (...), s ezek a gondolatok fénysugárként hatoltak át a sötétség és zürzavar birodalmán (...); s most itt állt az egész, tudománnyá szervezve és alakítva, végérvényes alapokra helyezve" (De Quincey [1821/1983] 134-135. o.).

A hajdani tantörténetek érvelésmódját követve az ilyen idézetek jó kiindulópontként szolgálnának ahhoz, hogy a kétszáz esztendeje született könyv aktualitását bizonygassuk, rámutatva egyebek között arra, hogy számos témájáról - így a gazdasági szabadságról $s$ annak egyik, Ricardo és a mai közgazdászok számára egyaránt kiemelten fontos összetevőjéről: a kölcsönös előnyökkel járó nemzetközi szabadkereskedelem koncepciójáról (a komparatív előnyök tana), a megszorítások politikáját alátámasztó, neki tulajdonított „ricardói ekvivalenciáról” vagy az absztrakt elmélet lehetőségeiröl és korlátairól - ma legalább akkora viták zajlanak, mint első megjelenése idején, a 19. században.

Bármennyire is kézenfekvő lenne az ilyesfajta interpretáció, mégsem tűnik járható útnak, mert ez a rekonstrukció az éppen adott jelen disputáinak résztvevőjeként élesztené újjá az „angol free-traderek apostolaként, századunk legkiválóbb közgazdászaként” (Marx [1848/1959] 426. o.), a „klasszikus politikai gazdaságtan betetőzőjeként" (Schumpeter [1914] 53-54. o.) méltatott gondolkodót. Így pedig aligha remélhetnénk támpontot ahhoz, hogy megértsük: mi adott és ad alapot a különböző, egymással éles vitában álló közgazdaságtani iskoláknak (neoklasszikusoknak, keynesiánusoknak, „neoricardiánusoknak”) ahhoz, hogy megpróbálják Ricardót a maguk számára szellemi elődként kisajátítani (A. Marshalltól N. Kaldoron át P. Sraffáig és S. Hollanderig), miközben ugyanezen irányzatok más jeles képviselői az ő káros befolyásának tulajdonították a közgazdaságtan évtizedes vagy évszázados eltévelyedését (W. Jevons, J. M. Keynes és élete végén J. Schumpeter). Az a kérdés is zárójelbe kerülne, hogy mennyire problematikus maga a klasszikus politikai gazdaságtan terminusa vagy annak ikercsillagaiként Smith és Ricardo egymás mellé rendelése.

E tanulmány már terjedelmi okból sem vállalkozhat az exponált és a további, Ricardo művével kapcsolatos kérdések részletes kifejtésére, de arra talán igen, hogy valamelyest segítse az olvasót eligazodni egy különös életút, egy rendkívüli szellemi teljesítmény és egy szerteágazó recepció egymásba fonódó történetében. Ilyen bevezetőt írni egy új kiadáshoz, harmadikként belépni (mondhatni: betolakodni) az eredeti szöveg és a mai olvasó közé persze legalábbis kétélü vállalkozás. Ricardo esetében a kéretlen idegenvezető mentségként arra hivatkozhat, hogy a könyvet már első megjelenésekor is nehéz olvasmánynak tartották, a British Review névtelen recenzense Ricardo „enigmatikus kifejtésmódjáról” panaszkodott, amivel „még a legegyszerübb 
kérdésekben is összezavarja az olvasó értelmét” ( $N$. N. [1817] 310. o.), s hasonló megjegyzésekkel a későbbi irodalomban is bőséggel találkozhatunk. ${ }^{1}$

A másik körülmény, ami viszont szinte lehetetlen feladattá teszi egy új Ricardo-elöszó megírását, az az 1951 és 1973 között megjelent, 11 kötetes Ricardo-összkiadás szerkesztőjének, Piero Sraffának az Alapelveket tartalmazó első kötethez írt, nagy bevezető tanulmánya, amely megkerülhetetlen és utánozhatatlan példa: alapvetően új irányt nyitott Ricardo és a klasszikus politikai gazdaságtan értelmezésében, míg az egész sorozat „aprólékos gondosságával, állandó józanságával és erudíciójával” (Stigler [1953/1965] 302. o.) megteremtette a közgazdasági szövegkiadás azóta is érvényes etalonját. Az összkiadásért Sraffa méltán nyerte el a Svéd Királyi Akadémia aranyérmét. ${ }^{2}$

A tanulmányban elöször röviden áttekintem Ricardo életét, majd felvázolom az új kötetben magyarul elöször megjelenő két pénzügyi értekezés hátterét. Ezt követően az Alapelvekből emelek ki néhány kérdést. Az új kiadás válogatása tartalmazza Ricardo utolsó, befejezetlen kéziratát is, amelyben a változatlan értékmérő problémájával viaskodik, és két parlamenti beszédét a választójogi reformról és a gépesítés hatásairól, amelyek segítenek kirajzolni az aktív politikai szereplö arcélét - a tanulmányban szemügyre veszem mindkét kérdéskört. Végezetül kitérek Ricardo recepciójának néhány, a cikk elején már szóba hozott mozzanatára, köztük a származás és a szemléletmód között vélelmezett összefüggésre, az úgynevezett „ricardói vétek” történetére és a Sraffa [1951] elöszava nyomán kibontakozott - nyugvópontra azóta sem jutott - vitára arról, hogy Ricardo-e a kiindulópontja az érték és a jövedelemelosztás elméletét a társadalmi többletre alapozó klasszikus közelítésmódnak, amely radikálisan különbözik a kereslet-kínálat szerepét hangsúlyozó neoklasszikus hagyománytól, s annak egyben meggyözö kritikája is (Kurz [2003]).

\section{„Az absztrakt és általános érvelés iránti érzéke már fiatalon megmutatkozott"3}

David Ricardo 1772. április 18-án született Londonban, egy szefárd zsidó család harmadik fiaként. Apja tőzsdeügynök volt a londoni Cityben, aki 1760-ban kezdett Londonban tevékenykedni, és 1770-ben lett brit alattvaló. A család gyökerei Portugáliába vezetnek, innen a 16. század végén az inkvizíció üldözései elől menekülve vándoroltak Livornóba, majd 1680 körül költöztek tovább Amszterdamba. Ricardo ifjúságáról keveset tudunk, egyetlen forrásunk az a rövid memoár, amelyet öccse, Moses Ricardo írt, eszerint apjuk Davidet „saját üzlete folytatójának” szánta, s ezért csak a „kereskedelmi élet” ismereteit tartotta számára szükségesnek, de semmiféle „klasszikus oktatásban”

\footnotetext{
${ }^{1}$ James Bonar a 20. század elején azzal védte Ricardót, hogy barátai sürgetésének engedve vállalkozott az átfogó értekezés megírására, holott igazi műfaja az egy kérdésre koncentráló pamflet volt, s ez okozta a koherencia és a stílus fogyatékosságait, „mintha a lírai költőnek eposzt kellene írnia” (Bonar [1911] 96. o.).

${ }^{2}$ 1930-ban Keynes javaslatára bízták meg Sraffát az összkiadás feladatával. Lásd Bharadwaj [1988], J. Hollander szerepéről Gehrke-Kurz [2002], M. Dobb közreműködéséről Pollit [1988].

${ }^{3}$ Moses Ricardo: A memoir (Ricardo [1951-1973] X. köt. 4. o.).
} 
nem részesült. 1783-ban, 11 éves korában Davidet apja az amszterdami rokonokhoz küldte nyelveket tanulni és megszerezni a szükséges üzleti tudást. A memoár szerint apja azt is szerette volna, hogy David abban az iskolában tanuljon, amelyet ő ,igen nagyra tartott", vagyis a híres amszterdami portugál zsinagóga Talmud-iskolájában (nem maradt fenn írásos bizonyíték arról, hogy ez valóban megtörtént-e). Harminc évvel később Ricardo úgy emlékezett, hogy nem érezte jól magát a rokoni házban, és csak hollandul tanult meg. Két évet töltött ekkor Amszterdamban, majd visszatérve Londonba, alig 14 évesen apja mellett kezdett dolgozni. Neve először 1793 januárjában szerepelt önállóan azokban a kimutatásokban, amelyeket a Bank of England vezetett az államkölcsönökkel üzletelő tőzsdealkuszok tranzakcióiról.

Nagykorúságát elérve, 1793 decemberében David Ricardo megnősült, egy kvéker sebész és gyógyszerész lányát vette feleségül (a házaspárnak nyolc gyermeke született). Ez a házasság (amelyet mindkét családfö ellenzett) kettős következménnyel járt: Ricardo elhagyta ősei vallását - anyja ezt haláláig nem bocsátotta meg, s a családi kapcsolatok csak az ő halála (1801) után álltak helyre -, egyszersmind távozni kényszerült az apai cégböl, és a pénzügyi piacon önállóan, családi tőke vagy támogatás nélkül kellett fellépnie. Saját tőkéje ekkor 800 font körül lehetett, de egy londoni bank, ,ismerve jellemét (...), bizalmáról biztosította, kilátásba helyezve, hogy elfogadja váltóit. Ez a segítség és Ricardo saját tehetsége elegendő volt, hogy önállóan kezdjen tevékenykedni, és néhány év alatt gazdagabb emberré lett, mint az apja."

Ricardo a saját számlára dolgozó tőzsdeügynökök egyike volt abban az időszakban, amikor a pénzügyi világot is megrázták a politika és a történelem viharai: a forradalmi, majd napóleoni Franciaország és Nagy-Britannia két évtizedes háborúja nyomán az államadósság nominális összege csaknem háromszorosára nőtt, és meghaladta a GDP 250 százalékát, 1797-ben szükségessé vált a font konvertibilitásának felfüggesztése, amit 1799-ben a jövedelemadó bevezetése követett. A háborús finanszírozás szükségletei, a monetáris és fiskális politika innovációi Ricardo számára elöször csak rendkívüli üzleti lehetőségeket jelentettek, s ő azokat nagyon jól ki is használta. Már 1798-ban azt írta egy levelében: „a szerencse igazságtalanul bőkezű volt hozzám" (Ricardo [1951-1973] X. köt. 113. o.), s a fiatal, de jómódú család számára az sem volt gond, amikor Ricardo feleségét a következő évben az orvosok a korszak divatos gyógyhelyére, Bathba küldték kúrára.

Hogy elüsse az időt, Ricardo itt kezdte olvasni Adam Smith könyvét, A nemzetek gazdagságát, s ettől datálható elméleti érdeklődése a politikai gazdaságtan iránt. Ám ekkor még a tudományok jobban érdekelték: matematikával, földtannal és kémiával foglalkozott, vegyi laboratóriumot rendezett be, ásványokat gyüjtött, s tagja lett az 1807-ben alapított londoni Geological Societynek, később pedig föúri ajánlásokkal az egyik elökelö londoni klubnak. Ez azonban csak időtöltés maradt, nem adott új dimenziót a tőzsdés életének. Ricardo üzleti tevékenységének előterében az értékpapírügyletek álltak, majd amikor 1806-tól kezdve megnőtt a fix kamatozású államkötvények szerepe az államháztartás finanszírozásában, a jegyzés és kibocsátás megszervezésére a bankok mellett ajánlatot tevő egyik tőzsdei konzorcium vezető alakja lett.

\footnotetext{
${ }^{4}$ Sunday Times, 1824. szeptember 13. (Ricardo [1951-1973] X. köt. 68. o.)
} 
Az 1811 és 1815 között kibocsátott kölcsönök mindegyikének ő volt az egyik megszervezője, s ezek közül az 1815-ös, 32 millió fontos kölcsön volt különösen nevezetes, amelyet az Elba szigetéről visszatérő Napóleon ellen kiújult háború tett szükségessé. A kibocsátás 1815. június 14-én történt, s a piac ezt eléggé nyomott hangulatban fogadta, de négy nappal később a waterlooi csata híre radikális fordulatot hozott, s a minden pénzét kötvényekbe fektető Ricardo élete legnagyobb nyereségét realizálta (bár az egyik nekrológjában szereplö, egymillió fontos profit nyilvánvalóan erős túlzás volt), „s így elég okom van rá, hogy az üzlettel meg legyek elégedve” (Ricardo [1913] 90. o., [1951-1973] VI. köt. 233. o.).

Mi volt a sikeres karrier titka? Az egyik kortársi emlékezés szerint: „úgy mondják, rendkívül gyorsan ismerte fel és használta ki a maga előnyére a piac minden fordulatát (...), soha nem vágott bele nagyméretü spekulációba, hanem amikor a piac megfordult, azonnal eladott, így kis százalékot nyert nagy összegeken" (idézi J. L. Mallet, lásd Ricardo [1951-1973] X. köt. 73. o.). Elegendö-e ennyi ahhoz, hogy valaki alig két évtized alatt bekerüljön a korabeli csúcsgazdagok 1 százalékába, és nagyon komoly vagyonra tegyen szert - a becslések szerint ennek értéke Ricardo halálakor elérte vagy meghaladta a hétszázezer fontot, ${ }^{5}$ vagyis mai pénzben számolva sokszoros milliomos volt -, erre a kérdésre nyilván nem itt kell válaszolni.

Ezt a tranzakciót követően Ricardo gyakorlatilag, majd formálisan is visszavonult a tőzsde világából (bár 1819-ben egyszer még versenybe szállt Nathan Rotschilddal az esedékes államkötvény kibocsátásának megszervezéséért). Részben új életet kezdett mint gazdag vidéki földbirtokos (country gentleman) és parlamenti politikus, részben pedig kiteljesítette a még 1809-ben pénzügyi szakíróként induló karrierjét, s néhány év alatt - saját maga számára is meglepő módon - az angol politikai gazdaságtan meghatározó, európai befolyású és tekintélyű alakjává vált. A földbirtokokkal együtt 1814-ben vásárolt egy kastélyt a délnyugat-angliai Gatcombe-ban, ${ }^{6}$ amely 1940-ig maradt a család birtokában (ma pedig Anna királyi hercegnő, II. Erzsébet lánya lakik benne). „Ezen a kellemes helyen nem fogok sóhajtozni az értéktőzsde és örömei iránt" - írta innen Malthusnak (Ricardo [1913] 43. o., [1951-1973] VI. köt. 115. o.). 1818-ban nevezték ki Gloucestershire high sheriffjének, ami bár elsősorban ceremoniális tisztséget jelentett, mégis jól tükrözte, hogy a visszavonult tőzsdés rövid idő alatt milyen tekintélyt szerzett a grófság birtokosai körében.

A rá következő évben Ricardo parlamenti képviselö lett - javarészt James Mill sürgetésére, akinek előzőleg, amikor mentorként az Alapelvek megírására és publikálására ösztönözte az írói és szónoki képességeiben egyaránt kételkedő barátját, ${ }^{7}$ megígérte, ha könyve Mill jóslatának megfelelően sikeres lesz, akkor ebben is fejet hajt. Az írországi Portarlington, egy jellegzetes rotten borough (romlott választókerület) mandátumát szerezte meg. Az ilyen körzetekben a többezres lakosságban csak néhányan rendelkeztek választójoggal, s az ő szavazatukat évtizedeken át általában a

${ }^{5}$ J. E. King szerint 2013-as árakon számolva évi jövedelme 15 millió fontot tett ki, teljes vagyona pedig 350-400 millió fontra rúgott (King [2013] 6-7. o.).

${ }^{6}$ Akkor még Gatcombe Park volt a neve.

7 „Nagyon szeretnék valami publikálásra érdemeset létrehozni, de őszintén félek, hogy nincs erőm hozzá" - írta 1816 novemberében Millnek (Ricardo [1951-1973] VII. köt. 88. o.). 
vidék meghatározó földbirtokos családja „irányította”. Ezúttal a súlyos pénzzavarral küzdő Earl of Portarlington a birtokaira kapott 25 ezer fontos jelzáloghitel és 4000 font egyösszegü kölcsön ellenében „gondoskodott” Ricardo megválasztásáról. Bár a radikális reform híveinek egyik legfőbb célkitüzése éppen az effajta politikai kegyuraságot lehetővé tevő „Old Corruption” rendszerének felszámolása volt, elfogadhatónak tartották, hogy ilyen módon szerezzenek lehetőséget elveik és javaslataik képviseletére a brit parlamentben. Ennek fonákságát politikai ellenfeleik természetesen szemükre is vetették, amint azt az arisztokrácia előjogai ellen, a választójog kiterjesztése mellett felszólaló Ricardo is megtapasztalta egy vitában: „sohasem tette be a lábát Îrországba (...) éppen az az arisztokrácia választotta meg, amelynek befolyását (...) ócsárolta" - gúnyolódott rajta egy másik írországi képviselő (Ricardo [2017f] 529. o.). A másik oldalon viszont ez azzal az előnnyel járt, hogy Ricardo teljesen függetlenül adhatott hangot politikai és gazdasági nézeteinek: „nem leszek sem tory, sem whig, de nagyon szeretnék támogatni minden javaslatot, amely esélyt ad arra, hogy jó kormányzatunk legyen, amit parlamenti reform nélkül soha nem fogunk elérni" (Ricardo [1951-1973] VII. köt. 260. o.). 1821-ben egyik alapító tagja a közgazdasági kérdések megvitatására és a helyes nézetek terjesztésére létrehozott, havonta ülésezö Political Economy Clubnak.

1822-ben Ricardo feleségével és két legfiatalabb lányával több hónapos európai körutat tett, amely a nevezetességek megtekintése mellett alkalmat adott más közgazdászokkal lebonyolított találkozókra is. Az eszmecserék (ahogy ez történni szokott) általában nem változtattak a résztvevők eltérő álláspontján, így például az egyik neves vitapartnerével, a svájci Sismondival való személyes megismerkedés sem. Ugyanez volt a helyzet az ekkor már egyetemi professzorként müködő, tekintélyes francia közgazdász, Jean-Baptiste Say esetében is, aki már évekkel korábban felkereste Ricardót Gatcombe Parkban, s egyik levelezőpartnere lett. Svájcban a Simplon-hágóra kirándulva, Ricardo egy fiatal lengyellel találkozott, aki azt kérdezte tőle, „ö-e a politikai gazdaságtanról szóló mủ szerzője?”. A fiatal lengyelt S. Kunattnak hívták, ekkor Párizsban volt ösztöndíjasként Say tanítványa, és tanára javaslatára olvasta az angol közgazdász könyvét (az Alapelvek első francia fordítása Say jegyzeteivel 1819-ben, az első német kiadás pedig 1821-ben jelent meg), néhány évvel később pedig ő fordította lengyelre és adta ki Ricardo fömüvét.

A könyv 1821-ben a gépekről és a gépesítés hatásáról szóló új (31.) fejezettel kibővítve és átdolgozva már harmadik kiadásban került ki a nyomdából, de az érték és az elosztás problémáit, köztük a változatlan értékmérő meghatározását Ricardo ekkor sem tekintette kielégítően megoldottnak. Visszatérve Angliába, ideje java részében erre próbált végérvényes választ keresni, miközben továbbra sem hanyagolta el azt a tárgyat, amelyben elöször lépett közgazdászként a nyilvánosság elé, $\mathrm{s}$ amely végigkísérte egész pályáján: a pénzelmélet és a bankok kérdéskörét. Mint már említettük, az új magyar kiadás második - Válogatás egyéb írásokból és parlamenti beszédekből címü - részében található az a két utolsó írása (Egy nemzeti bank terve, Abszolút érték és csereérték - Ricardo [2017d], [2017e]), amelyek publikálására, illetve végső formába öntésére már nem volt módja; rövid szenvedés után, 1823. szeptember 11-én, 51 évesen egy fülgyulladás szövődményeibe halt bele. 


\section{Leértékelödés, konvertibilitás és a központi bank létrehozása - pénzelméleti írások}

Egy tőzsdealkusz esetében aligha meglepő, hogy nemcsak anyagi és társadalmi felemelkedését, de közgazdászi pályáját is bizonyos értelemben a pénz határozta meg, első, még névtelenül megjelent újságcikkeitől a nemzeti bank létrehozását javasló tervezetéig. A késői indulás már inkább kíván magyarázatot, hiszen amikor 1809 augusztusában, 37 évesen bekapcsolódott abba a vitába, amely az angol font konvertibilitásának 1797-ben történt felfüggesztését követően zajlott a következményekről és a teendőkről, már évtizedes tapasztalatokat szerzett a pénz- és tőkepiacon. Az eredetileg a kialakulóban lévő bankpánik megállítását, a nemesfémtartalék védelmét célzó, rövid távúnak gondolt, de 24 évig hatályban tartott intézkedés ellenzői, a későbbi „bullionista” álláspont szószólói szerint ez a bankjegyek túlzott kibocsátásához, az áruk, a tömbarany, a tömbezüst és a külföldi valuták árának emelkedéséhez, valamint a font leértékelődéséhez vezetett, amit csak a konvertibilitás azonnali helyreállításával lehet orvosolni.

John Law kudarccal végződött kísérletének emléke az arany demonetizálására 1720-ban és a francia asszignáták rohamos elértéktelenedésének korabeli tapasztalata egyaránt a konvertibilitás feltétlen szükségességét hangoztató bullionista álláspont mellett látszottak szólni, ám az 1797-es intézkedést nem követték hasonló drámai fejlemények. A tömbarany piaci ára szilárdan megmaradt a pénzverdei hivatalos árfolyamon, egy uncia arany továbbra is 3 font 17 shilling 10 és $1 / 2$ pennyt ért, valószínüleg részint azért, mert a gazdasági tranzakciók jelentős részét már addig is bankjegyekkel bonyolították le, részint mert a Bank of England óvatosan járt el a pénzkibocsátás növelésében. A vita csak akkor robbant ki, amikor a tömbarany ára 1799-ben emelkedésnek indult, és 1801 januárjára elérte az unciánkénti 4 font 6 shillinges szintet, ${ }^{8}$ vagyis a font, a beválthatatlan papírpénz számottevően leértékelődött. A fémpénz és a papírpénz viszonyát taglaló szerzők egyik csoportja szerint az áruárak és a tömbarany áremelkedése, valamint a váltóárfolyam leértékelödése „a bankjegykibocsátás növekedésének szükségszerü következménye (...) ez éppoly állandóan működő elv, mint a gravitáció törvénye" (Boyd [1801] 7. o.). A másik oldal viszont úgy látta, hogy a Bank of England által kibocsátott papírpénz mennyisége „soha nem haladta meg a közönség szükségletét (...), és nem okozott semmiféle emelkedést az élelmiszerek árában" (Baring [1801] 7. o.).

A vita további menetét itt nincs mód követni, azt azonban szükséges megjegyezni, hogy 1802-ben jelent meg Henry Thornton könyve (Thornton [1802]), amelyet Hayek nyomán ma sokan nemcsak a Bullion-vita, hanem az egész klasszikus periódus legfontosabb pénzelméleti munkájának tartanak, bár besorolásán máig vitatkoznak, mivel Thornton elméletileg az aranystandard híve volt, ugyanakkor szükségesnek tartotta a konvertibilitás felfüggesztését a háború idején, és védelmébe vette a Bank of England 1797 utáni politikáját, kidolgozva a „végső kölcsönadó” elméletét. Thornton

\footnotetext{
${ }^{8}$ Hawtrey [1919] szerint az aranyár 1801-ben 109 százalékon állt (269. o.).
} 
és a többi „mérsékelt bullionista” alapjában elfogadta a túlzott pénzkibocsátást a magas aranyár és a leértékelődő árfolyam hosszú távú magyarázataként, de lényegesen összetettebb elemzést adott a pénzmennyiség, az ár- és jövedelem-színvonal, a forgási sebesség, a fizetési mérleg stb. viszonyáról. Thornton érvelése szerint a tömbarany ára akkor is emelkedhet, ha nincs túlzott papírpénz-kibocsátás, az árfolyamesést okozhatja a kereskedelmi mérleg vagy a fizetési mérleg kedvezőtlen alakulása: a rossz termés miatt szükséges import, illetve a kontinensen viselt háború és a háborús szövetségesek pénzügyi támogatása.

A vita első szakasza az évtized közepére elcsendesedett, az arany piaci ára és a váltóárfolyam csökkenni kezdett, sőt néhány adat szerint visszatért az 1797-es szintre. 1809-re azonban a tömbarany piaci ára 15 százalékkal emelkedett a pénzverdei ár fölé (decimális formában kifejezve 1 uncia körülbelül 3,89 fontról körülbelül 4,50-re), a váltóárfolyam Hamburgban és Párizsban is körülbelül 20 százalékkal a paritás fölött volt.

Mindez „bár felkeltette a közvélemény figyelmét, de az emberek nincsenek kellöképpen tisztában sem a tárgy jelentőségével, sem azokkal a katasztrofális következményekkel, amelyekkel a papír további leértékelődése járhat" (Ricardo [1951-1973] III. köt. 15. o.). Ezzel a megállapítással indította az ekkor még a névtelenség homályát választó Ricardo a Morning Chronicle nevü, a whig politikát támogató lapban 1809 augusztusában megjelent első levelét, amely alapjául szolgált a rá következő évben már saját neve alatt, önálló értekezésként közzétett (A tömbnemesfém magas ára - a bankjegyek leértékelődésének bizonyitéka címü) írásnak (Ricardo [2017c]). Bár a pamflet (angolban ez a kifejezés - a magyartól eltérően - kisebb könyvet, vitairatot jelöl, de nem támadó gúnyiratot értenek alatta) szerzője szerint „nem bővítette azoknak az ismereteknek a körét, amelyekkel sok kiváló szerző világosította fel a közt”, mégis igen sikeresnek bizonyult (Ricardo [2017c] 478. o.). Egy év alatt négy kiadásban jelent meg, és Ricardót egy csapásra a politikai gazdaságtan tekintélyes gondolkodói közé emelte, megszerezve neki számos pályatársa elismerését, köztük a már korábban említett Malthus és James Mill életre szóló barátságát. Ricardo írása azonban nem csak a közgazdász pályakezdésének dokumentumaként fontos, ez nyitotta meg a Bullion-vita második szakaszát, amely egy parlamenti bizottság jelentésében és az arról folytatott vitában csúcsosodott ki 1810-1811-ben.

Ricardo szándéka a pamfletben egyértelmű volt: kimutatni „a politikai gazdaságtan bevett elvei alapján (...), hogy az ország papírpénze (...) jelentősen leértékelt, abból eredően, hogy túl sok van belöle, nem pedig amiatt, hogy ne lenne meg a bizalom a Bank of England iránt, vagy kétség merülne fel azt illetően, hogy képes teljesíteni a kötelezettségeit" (uo. 437. o.). Érvelésében abból indult ki, hogy szét kell választani a tömbarany piaci árának emelkedését és a pénz értékének csökkenését. Az előbbi az arany piacán végbemenő változást tükrözi, az utóbbi a pénz oldalán történik, amit a tömbarany piaci ára és az aranypénz hivatalos ára között növekvő különbség mutat. Ha valaki - miként Ricardo szerint Thornton - ezt elmulasztja, akkor az érvelése hibás: „nem tesz különbséget az arany értékének és az arany pénzben kifejezett árának az emelkedése között” (uo. 445. o.). Ez a distinkció a vita lényegéhez vezet: Ricardo

\footnotetext{
${ }^{9}$ Lásd O’Brien [2004] 177. o. Ezt vitatja De Boyer des Roches-Solis Rosales [2016] 173. o.
} 
szemében az arany elsősorban áru, és csak azután pénz, értékét a ritkaság, a megszerzésére fordított munka és felhasznált tőke mennyisége határozza meg, s ha ezek változatlanok, akkor a tömbarany piaci és az aranyérme rögzített ára közötti különbséget vagy a pénzrontás (ami miatt 1696-ban az ezüstérméket, 1774-ben pedig az aranypénzeket be kellett vonni és újraveretni), vagy a túlzott bankjegykibocsátás okozza. Mivel az aranyérmék megtartották hivatalos nemesfémtartalmukat, ezért a magyarázatot nem az arany, hanem a pénz oldalán kell keresni. „... a forgalmi eszköz a fölös mennyiség következtében szükségszerủen leértékelődik, és ezt a leértékelődést - az ország pénzének szokásos állapota mellett - a nemesfémek exportja ellensúlyozza." (Uo. 448. o.) A font árfolyamának csökkenése nincs összefüggésben a mérleghiányt okozó reálgazdasági tényezőkkel, a magas tömbaranyárnak tehát egyetlen oka van: a konvertibilitás felfüggesztése nyomán a Bank of England lehetőséget kapott a túlzott papírpénz-kibocsátásra, és élt is vele, ami előidézte a font leértékelődését.

A diagnózisból egyértelmü terápia következik: a megoldást ilyen körülmények között nem a reálgazdasági problémák elmúlásától vagy automatikus egyensúlyi mechanizmusoktól lehet várni, hanem csakis attól, ha a Bank of England fokozatosan csökkenti a forgalomban lévő bankjegyek mennyiségét, mindaddig, amíg ezek értéke egyenlővé nem válik az általuk képviselt érmék értékével, „vagyis, más szóval, amíg a tömbarany és tömbezüst ára le nem megy a pénzverdei ár szintjére" (uo. 473. o.). Ricardo okfejtésének egyik alapfeltevése, hogy az arany kivitelét „nyugodtan az egyének belátására lehet bízni”, mert itt is, akárcsak általában a kereskedelemben, „szabad verseny mellett a kereskedelem terén az egyén érdeke és a közösség érdeke sohasem térhet el egymástól" (uo. 441. o.).

Ha azonban ez az általános elv, akkor miért kell a magánbankként müködő, de sajátos monopoljogokkal rendelkezö és a kormányzat fiskális ügynökeként fellépő Bank of England „oktalan eljárását” normatív módon korlátozni? Noha a független bank igazgatóinak a részvényesek érdekében kellett cselekedniük, Ricardo szerint a háborús finanszírozás időszakában és adott módja mellett a bank már nem viselkedhetett független szereplőként: „megkérdőjelezhető, hogy az a bank, amely sok millióval többet kölcsönöz a kormánynak, mint amennyi a tőkéje és a megtakarításai, ettől a kormánytól függetlennek volna tekinthetö" (uo. 477. o.). Ezért közérdek a konvertibilitás mielőbbi helyreállítása, ami megvéd a bank „intézményi természetéből” fakadó és az 1797-es „politikai riadalomhoz” hasonló helyzetek káros következményeitől. Az „intézményi természet” kifejezéssel Ricardo azt nyomatékosította, hogy bár a bank igazgatóit és részvényeseit „kereskedők olyan kompániájának” látta, akik „hírhedten tudatlanok a politikai gazdaságtan legnyilvánvalóbb elveit illetőleg”, miközben „kedvük szerint szabályozhatják a közösség tulajdona jelentős részének értékét" (Ricardo [1951-1973] III. köt. 133. o.), de - mint ezt a parlamenti whig ellenzék vezetöjének írt levelében kifejtette - személyes integritásukat nem vonta kétségbe (uo. VI. köt. 70. o.). Inkompetensnek tartotta öket, nem korruptnak, s ehhez azt is hozzátette, hogy monopolhelyzete miatt a bank jobb üzletpolitikával a ténylegesen realizált profit kétszeresét is elérhette volna (uo. VIII. köt. 27. o.).

A pamflet hatását jól érzékelteti, hogy a kibontakozó vitában egyik ellenlábasa egyenesen őt tette meg a magas aranyár okait vizsgáló parlamenti bizottság 
1810 augusztusában közreadott jelentése (a Bullion Report) valódi szerzőjének: Bosanquet szerint Ricardo írása a jelentés „sillabuszának” tekinthető, vagyis mintha a viták újonc szerzője szabott volna irányt a bizottság (amelynek tagja sem volt) későbbi elemzésének és javaslatának (Bosanquet [1810] 2. o.). Bár ez polemikus túlzás, de annyit joggal lehet állítani, hogy 1810-től kezdve Ricardo lett a monetáris viták meghatározó figurája, ő vette át azt a szerepet, amelyet az előző szakaszban Thornton töltött be.

Amikor 1815-ben véget ért a Napóleon ellen vívott háború, és napirendre került a konvertibilitás visszaállítása, Ricardo javaslatot dolgozott ki, majd publikált a „biztonságos és gazdaságos valuta" bevezetésére, s ennek szövegéből hosszan idézett az Alapelvek 27. fejezetében (lásd Ricardo [2017b] 372-376. o.), amely egyesíteni kívánta az addig ismert különböző európai bankrendszerek előnyeit. Kettős célt akart elérni: kiiktatni és papírpénzzel helyettesíteni az aranyérméket a belső forgalomban és biztosítani a pénz értékállóságát. A papírpénz értékét az aranyalap fenntartása, a teljes konvertibilitás hivatott biztosítani és szabályozni, de a papírpénzt csak tömbfémre (ingot, innen a javaslat neve: Ingot Plan) lehet átváltani. Ez a javaslat 1819-ben került ismét elötérbe, amikor a kormány és a parlament már időszerünek és szükségesnek ítélte a visszatérést a konvertibilitáshoz az 1797-es árfolyamon. Ricardo képviselöként ekkor már tagja volt az illetékes parlamenti bizottságnak, amely (s nyomában a parlament) lényegében az ő tervezetét fogadta el a teljes konvertibilitás visszaállítását megelőző kétéves átmeneti időszakra - „győzelem a tudomány és az igazság számára”, írta erről egy levelében (Ricardo [1951-1973] VIII. köt. 44. o.).

A győzelem azonban nem bizonyult maradandónak, mert a parlament a Bank of England nyomására olyan kiegészítést füzött a törvényhez, amely később már választást engedett a banknak, hogy tömbfémben vagy érmében teljesíti kötelezettségét. A terv 1820-1821 közötti tényleges müködése nem hozott komoly gyakorlati változást: a pénzverde által szállított 2028 lepecsételt aranytömbből (a közvélemény ezeket „ricardóknak” hívta) csupán 13 került átváltásra, vagyis sikeres volt abban az értelemben, hogy nem indukált keresletnövekedést és áremelkedést az aranypiacon, ami érthető is, hiszen a háború utáni deflációban az arany piaci ára erre az idöre már a pénzverdei ár alá csökkent.

Ugyanakkor már abban az időben is voltak, akik élesen támadták őt a parlamentben és a nyilvánosság elött az ország „páratlan és súlyos ínségéért”, amelyet nem a Gondviselés okozott, hanem emberi kéz: „a pusztító pénzszűke” (Western [1822] 7. o.). Ricardo viszont arról volt meggyőződve, hogy a Bank of England aknamunkája torpedózta meg terve teljes sikerét, és ezért tovább kereste a módot arra, hogyan lehetne megszabadulni „a teljesen felesleges intézménytől, amely meggazdagszik azokból a nyereségekből, amelyek tulajdonképpen a közönséget illetik". Malthusnak 1815 szeptemberében írt levelében kifejtette, hogy a bankjegykibocsátást a pénzverés egy fajtájának kell tekinteni, „olyan előjognak, amely kizárólag az államot illeti meg”. Azt is elfogadhatatlannak tartotta, hogy hiába kötelezi szabadalomlevele a bankot arra, hogy a nyereségét évenként kiossza és számadásait bemutassa a részvényeseknek, „de a bank igazgatósága, úgy látszik, nem sokat törődik a törvényekkel” (Ricardo [1913] 94. o., [1951-1973] VI. köt. 268-269. o.). 
A megoldást egy nemzeti bank létrehozásában látta, s ennek tervét 1823 nyarán, nem sokkal halála előtt vetette papírra (lásd a most megjelent kötetben az Egy nemzeti bank terve címü szemelvényt - Ricardo [2017d]), s ezt testvére, Moses Ricardo jelentette meg a következö évben. A rövid írás ugyan részben folytatta az Alapelvek vonatkozó fejezetének gondolatmenetét, de legalább két tekintetben fontos változásról tanúskodott Ricardo gondolkodásában. Az egyik: szétválasztva a papírpénz-kibocsátást és a hitelellátást, az elsőt egy monopoljogokkal felruházott, a kormánytól és a többi banktól független testületre kívánta bízni, míg a másodikat meghagyta volna a szabad piacon versengő magánbankok üzleti tevékenységeként. Elképzelése szerint a nemzeti bank nem nyújthat kölcsönöket a kormánynak, az maga kell hogy finanszírozza kiadásait. A bankjegykibocsátásban abszolút monopólium, a hitelpiacon továbbra is verseny - ez nyilvánvaló eltérés attól, ahogyan Ricardo korábban Smith nyomán a szabad piac általános érvénye mellett érvelt a monetáris szférában. A másik: ebben a szövegben indokoltnak látta, hogy a pénzforgalom alakulásától függően a biztosok, vagyis a jegybank állampapírok vételével vagy eladásával (azaz a későbbi terminológiát használva diszkrecionális módon), nyíltpiaci műveletekkel avatkozzanak be, és szabályozzák a pénz mennyiségét, ami lényegesen különbözik a későbbiekben - a 19. század középső harmadában - rá hivatkozó „monetáris ortodoxia” álláspontjától, amely csak a normatív szabályozást és az annak révén megvalósuló automatikus alkalmazkodást tekintette helyesnek (Arnon [2011], Deleplace [2015]).

\section{Gabonatörvény, védővámok és a profit alakulása}

A „testhezálló” pénzügyi elemzések és javaslatok mellett Ricardót a háborús időszak vége felé más aktuális kérdések is foglalkoztatták, amire részben a gabonakereskedelem korlátozását célzó, a brit termelőket az olcsóbb külföldi gabonabehozatal ellen védő törvény parlamenti vitái is ösztönözték. Levelezésében 1813-tól kezdve már többször feszegette azt a problémát, hogy milyen összefüggés áll fenn a mezőgazdasági termelés körülményei, az élelmiszerárak és a többi ágazatban elérhető nyereség, az általános profitráta között. 1815-ben ugyanabban a hónapban került ki a nyomdából Malthus és Edward West írása, amelyek „egyszerre tárták a világ elé a földjáradék helyes elméletét", és Ricardo esszéje (An Essay on the Influence of a Low Price of Corn on the Profits of Stock - Ricardo [1815/1951]), amely egy csapásra volt aktuális politikai röpirat és a későbbi főmü gondolatmenetének megelőlegezése. Piero Sraffa az Alapelvekhez írt elöszavában úgy fogalmazott, hogy itt jelentek meg annak az új értékelméletnek az első, még töredékes elemei, amelyeket két évvel később, a könyv 1. fejezetében már általános érvényü magyarázatként fejtett ki (Sraffa [1951] XXXIXXXII. o.). Hogy ehhez eljusson, Sraffa szerint Ricardónak elemzési eszközként azt a „gabonamodellt” kellett használnia, ,amely ugyan sehol sem található fennmaradt leveleiben és írásaiban", de lehetővé tette, hogy egyetlen szektorra, a mezőgazdaságra redukálva a gazdaságot, annak egyetlen termékében, gabonában fejezze ki az előlegezett tőkét és a termelés eredményét, vagyis ezek különbségeként úgy határozza meg a profitot és annak rátáját természetben, hogy értékelésre ne legyen szükség. 
Az Essay valóban tartalmazott egy táblázatot, amely gabonában szemléltette a profit és a járadék alakulását nyolc egymást követő időszakban, ahol a pótlólagos tőkebefektetések csökkenő hozama következtében a járadék aránya folyamatosan nő a profit rovására. Ebben a táblázatban egyetlen heterogén tényező szerepelt: az egymás után művelés alá vett, csökkenő termékenységü földterület. Amint Ricardo Malthusnak írta 1815-ben: „ez az egyszerü elmélet (...) könnyü és természetes magyarázatot ad”, elkerülhetővé teszi „a nehézségek zürzavarát” (Ricardo [1913] 85. o., [1951-1973] VI. köt. 214. o.), s ha ez érvényes többszektoros, heterogén jószágokat előállító gazdaságra is, „akkor a járadék, a bér és a profit nagy kérdéseit azokból az arányokból kell megmagyarázni, ahogyan a teljes termék megoszlik a föld, a tőkések és a munkások között, s amelyek nem szükségszerủen kapcsolódnak az érték elméletéhez" (Ricardo [1951-1973] VIII. köt. 194. o.). Az utóbbi idézet egy 1820-as levélből való, s azt bizonyítja, hogy Ricardo még az Alapelvek második kiadása után is analitikusan szétválaszthatónak vélte a három nagy társadalmi osztály közötti jövedelemelosztás kérdését a mérés, az érték és az árak problematikájától, annak ellenére, hogy főművének említett 1., az értékröl szóló fejezetében éppen azokkal a nehézségekkel küszködött, amelyek többszektorú és többtermékes gazdaságban a változatlan értékmérő meghatározásánál a tőke heterogenitása miatt felmerülnek.

Mielőtt azonban ezeket megkísérelnénk összefoglalni, előbb az Essay aktuálpolitikai érvelése és a korabeli közgazdasági elemzés néhány összefüggését kell szemügyre vennünk. „[Ú]gy látom, hogy Ön teljesen lemondott a pártatlanságról (...) nyíltan és kifejezetten a behozatal megszorításáért emel szót" - írta Ricardo (Ricardo [1913] 66-67. o., [1951-1973] VI. köt. 177. o.), nem palástolva csalódottságát, barátjának, levelezö- és vitapartnerének 1815 februárjában, amikor a nagy egyetértéssel fogadott járadékelmélet után elolvasta Malthus másik, egy héttel később megjelent írását a gabonatörvény kérdésében, amely éles fordulattal a gabona szabad kereskedelme ellen foglalt állást. A vita egyszerre volt aktuálpolitikai és elméleti: milyen viszonynak kell lennie az első számú kereskedelmi és ipari hatalommá váló Nagy-Britanniában a különböző gazdasági szektorok és osztályok között, mitől függ a növekvő népesség és tőkefelhalmozás világában a különböző osztályok részesedése és jóléte? Malthus két érvet hozott fel a hazai mezőgazdaság védővámokkal történő támogatása mellett: az élelmiszer-behozataltól való függés veszélyét és az olcsó külföldi gabona miatt bekövetkező mezőgazdasági áresést, ami csökkenő mezőgazdasági profitot és növekvő munkanélküliséget eredményez: „kikötőink megnyitása a társadalom nagy tömegei számára nagyobb kárt, mint hasznot hozna" (Malthus [1815] 42. o.).

$\mathrm{Az}$ autarkia nemzetbiztonsági jelentőségére hivatkozó érvelésre válaszul Ricardo az exportáló és importáló ország kölcsönös függőségére mutatott rá, a második érvet pedig Malthus népesedés- és járadékelméletét alkalmazva cáfolta. A profitráta csökkenésének korabeli magyarázataival szemben, amelyek azt többnyire a kereslet-kínálat, a tőkefelhalmozás és a nyereséges beruházási lehetőségek közötti arány összefüggésében tárgyalták, Ricardo a profit általános szintjét hosszú távon a mezőgazdaság csökkenő hozadékából vezette le: „a gazdálkodó profitja szabályozza minden más gazdasági tevékenység profitját". Növekvő népesség, tőkefelhalmozás, a jó minőségü földek adott kínálata mellett és a technikai haladás, avagy az olcsóbb gabonaimport 
hiányában az élelmiszer-termelés növelésével „a gazdálkodó profitjának csökkennie kell az ott alkalmazott tőke minden növekedésével (...), s ezzel együtt minden más profitnak és a kamatlábnak is" (Ricardo [1951-1973] VI. köt. 104. o.). A politikai gazdaságtan nyelvén ez azt jelenti, hogy növekvő gazdaság és népesség esetén a társadalom összjövedelmében a földbirtokosok járadéka és a másik két osztály jövedelme fordított arányban áll egymással, s ezért „,a földbirtokos érdeke mindig ellentétes a társadalom minden más osztályának érdekével. Akkor megy jól neki, amikor az élelem szükös és drága, mindenki másnak viszont az olcsó élelmiszer az előnyös." (Uo. V. köt. 21. o.) A tőzsdeügynök életformájából ekkor éppen a földbirtokosok világába átnyergelő Ricardo e tételével nemcsak Malthust cáfolta, hanem azt is kétségbe vonta, amit Smith óta a politikai gazdaságtani narratívák java része elfogadott a mezőgazdaság és a földbirtokos szerepéről az ország gazdasági és politikai életében.

\section{„Egy könyvet kell írnom, hogy Önt meggyőzzem”}

Az Essay nem befolyásolta a politikai döntést, a parlament márciusban megszavazta a gabonabehozatal korlátozását, s Ricardo abban is tamáskodott, hogy a politikai gazdaságtan müvelői közül egyáltalán olvasta-e valaki a „rosszul kivitelezett (...), még a témákat ismerők számára is érthetetlen" okfejtést (Ricardo [1913] 68. o., [1951-1973] VI. köt 179. o.). Két körülmény ösztönözte a folytatásra: James Mill az elözőkben már említett folyamatos sürgetése és Malthus ellenvetései. „Mill azt kívánja, hogy részletesen írjam újra, de félek, ez meghaladja erőmet." (Ricardo [1951-1973] VI. köt. 249. o.) A skót filozófust és történészt, az utilitarista filozófusok csoportjának fö szervezőjét ez nem ingatta meg, s azzal igyekezett meggyőzni vonakodó barátját, hogy vagyona immár módot ad, hogy idejét erre fordítsa, képességei pedig alkalmassá teszik, „hogy bárki másnál sokkal jobban tökéletesítse ezt az annyira fontos tudományt (...) barátságom ön, az emberiség és a tudomány iránt egyaránt arra sarkall, hogy addig ne hagyjam nyugton, amíg egészen bele nem merül a politikai gazdaságtanba" (uo. 252. o.).

Így is történt: Mill részletes instrukciókkal látta el, hogyan fejtse ki és bizonyítsa álláspontját, hogyan ossza be idejét, hogy a sürü családi, baráti és társadalmi kötelezettségek mellett módja legyen müvén dolgozni stb. Ez az ,iskolamesteri” szerep azonban - szemben a korábbi irodalom ama véleményével, amely az utilitarizmus alapítójának, Benthamnek az állítólagos megjegyzésére („ő volt Mill szellemi apja, Mill pedig Ricardóé, így szellemi értelemben Ricardo Bentham unokája" - uo. 28. o.) támaszkodott - nem gyakorolt érdemi befolyást Ricardo politikai gazdaságtani elméletére. Nem gyakorolhatott, mert Mill jól tudta, hogy ekkor már Ricardo „a politikai gazdaságtan legjobb gondolkodója”, s az ő szerepe csak annyi, hogy ráhatásával a „legjobb szerzővé” is váljon. Közelebb áll az igazsághoz, hogy Mill befolyása más téren volt számottevö, nevezetesen a politikai szereplésre „vállalkozó” Ricardo felkészítésében.

Másként állt a helyzet Malthus esetében, aki számos ellenvetést tett a bér, a profit és a járadék kérdéseiben. Szerinte Ricardo nehézségeit az írásban az okozta, hogy rossz nyomon indult el, amikor „minden árat munkával akart meghatározni, és kizárta a tőkét a kereslet és kínálat nagy mechanizmusának müködéséböl” (uo. VII. 
köt. 30. o.). Ezzel szemben: „[n]em az-e az igazság minden esetben, hogy a járadék a kereslettől függ, összehasonlítva a jó földek kínálatával, a bér a kereslettől függ, összehasonlítva a munka kínálatával, és a profitok a kereslettöl függnek, összehasonlítva a tőke kínálatával?” (Uo. 77. o.) Ricardo leveleiben és személyes találkozásaik során részletesen igyekezett válaszolni Malthus érveire, amelyeknek alapeszméjével nem értett egyet, ${ }^{10}$ hozzátéve: „[e]gy könyvet kell írnom, hogy önt meggyőzzem” (Ricardo [1913] 112. o., [1951-1973] VII. köt. 10. o.).

Az Alapelvek 1817. április 19-én jelent meg, $s$ a fogadtatás rácáfolt Ricardo korábbi félelmeire: „nézeteim bármennyire helytállók lehetnek, soha nem leszek olyan szerencsés, hogy olyan művet hozzak létre, amely híressé és elismertté tesz" (Ricardo [19511973] VI. köt. 315. o.). És ezek a félelmek nem voltak indokolatlanok, a szöveg szerkezeti és stílusproblémái, a gyakorta nehezen követhető absztrakciók és levezetések azóta is sok fejtörést okoznak a könyv olvasóinak. S visszatérően felvetik azt a kérdést, melyet Donald Winch nyomán Ricardo-paradoxonnak lehetne nevezni: hogyan válhatott ez a kötet „a klasszikus politikai gazdaságtan” másik alapműveként maradandóvá és egyenrangúvá Adam Smith nagy művével, amikor annyira különbözik tőle erudíciójában, intézményi és történeti látókörében, retorikai eleganciájában stb.

Ez a különbség részben természetesen adódott a felvilágosodás nagy skót filozófusa és a forradalmak korának első időszakában élt autodidakta közgazdász személyes és történelmi helyzetének, tudásának és „víziójának” különbségéből, részben következménye volt Ricardo tudatos stratégájának is. Miként előszavában kifejtette, elsősorban Smith (és Say) nézeteit akarta korrigálni, nyersanyagként hasznosítva A nemzetek gazdagsága gazdag ismeretanyagát, miközben hallgatólagosan elfogadta az onnan merítettek java részét, $s$ a fejezetek sorrendjét is részben onnan vette. A politikai gazdaságtan absztrakt jellegét illető módszertani kérdésekben pedig sokszor Malthus ellen vívta a csatákat, noha valódi ellenlábasa Adam Smith volt: „,[a] politikai gazdaságtan az ön felfogása szerint vizsgálódás a gazdagság természetéről és okairól, én pedig inkább úgy gondolom, hogy ez a tudomány azon törvények vizsgálata, amelyek meghatározzák az iparkodás termékének elosztását az osztályok között, amelyek részt vesznek létrehozásában. A mennyiséget illetően nem találhatunk törvényeket, de az arányok tekintetében türhetően helyes törvényeket állapíthatunk meg. Napról napra mindinkább meg vagyok győződve arról, hogy az első hiábavaló és csalóka, és csak az utóbbi a tudomány igazi tárgya." (Ricardo [1913] 172. o., [1951-1973] VIII. köt. 278-279. o.)

A könyv nagyjából három egyenlő részre tagolható: az első hét fejezet az elméleti modell kifejtését tartalmazza, utána tizenegy fejezet a különböző adókat tárgyalja, végezetül az utolsó tizenhárom fejezetben számos fontos téma és sok polémia kerül egymás mellé, de ezek sorrendjének logikája kevéssé nyilvánvaló. ${ }^{11}$ A korábbi írás

${ }^{10}$ „Ön azt mondja, a kereslet és a kínálat szabályozza az értéket. Ez, azt gondolom, semmit sem mond (...) az értéket a kínálat szabályozza, ezt pedig a termelés komparatív költsége.” (Ricardo [1913] 173. o., [1951-1973] VIII. köt. 279. o.)

${ }^{11}$ A már idézett De Quincey volt talán az első, aki már 1824-ben megpróbálta átrendezni a fejezetek sorrendjét, szétválasztva a kifejtő és a polemikus részeket. Példáját követve számosan kísérelték meg logikus rendbe állítani az egyes fejezeteket. E kísérletekről írta némi malíciával Jacob Hollander 1910- 
analitikus alapeszméjét, hogy növekvő gazdaságban a profit és a járadék ellentétes irányú trendet követ, természetesen megtartotta, de a bizonyításon változtatnia kellett. Mivel a könyv elöszavában megismételte a levelezésből már idézett állítását, hogy a politikai gazdaságtan alapkérdése a különböző osztályok közötti jövedelemelosztást szabályozó törvények meghatározása, ennek általános kifejtéséhez már nem volt elegendő az egyszerü és homogén gabonamodell, a gazdaság mint egyetlen óriási farm ábrázolása, a bér, a profit és a járadék kapcsolatának elemzéséhez szüksége volt az érték és az árak elméletére.

A könyv 1 . fejezete, amely Schumpeter és mások szerint joggal tarthat igényt a legnehezebben olvasható klasszikus ökonómiai szöveg címére, s amelyet a marxista hagyomány az értéktöbblet elméleteként, a marginalista narratíva pedig a relatív árak elhibázott magyarázataként olvasott, valójában azt kereste, hogyan lehet egységes mértékegységben ábrázolni a profit hosszú távú csökkenő tendenciáját. A bérek és a profit ellentétes mozgásának ábrázolásához Ricardo itt már a munkaráfordítást használta a heterogén javak összevetésének közös nevezőjeként, a pénzt pedig a többi áruhoz hasonlóan munkatermékként kezelve igyekezett kizárni a pénz értékváltozásából fakadó nominális ár- és jövedelemváltozások hatását. Erre azért volt szüksége, mert Malthus ellenvetései nyomán kénytelen volt elfogadni, hogy a munkások fogyasztásába kerülő különböző termékeket eltérő álló- és forgótőke aránnyal, eltérő megtérülési idővel stb. állítják elö, ezért a relatív árak nemcsak a munkaráfordítások változása következtében változhatnak, hanem akkor is, ha a jövedelmek változnak. A bérek növekedése miatt a munkaigényes termékek ára akkor is nőni fog a tőkeigényes javakéhoz képest, ha a munkaráfordítás egyik területen sem változik. Ricardo elismerte, hogy tétele a munkaráfordítás kizárólagos értékmeghatározó szerepéről „szigorúan véve nem egészen igaz”, de a viszonylagos értékváltozások mércéjeként „jobban megközelíti az igazságot, mint bármely más tétel”, s ezért „könyvem első fejezete nem fog lényegesen változni, ami pedig a benne foglalt elveket illeti (...) teljesen változatlan marad" (Ricardo [1951-1973] VIII. köt. 279-280. o.). ${ }^{12}$

Máig vitatott kérdés az irodalomban, hogy miként kell értelmezni azokat a változtatásokat, amelyeket Ricardo könyve harmadik kiadásában (1821, az 1819-es második kiadás nem tartalmazott lényeges módosításokat) az 1. fejezeten eszközölt; elméleti visszavonulásról (S. Hollander), lényegében változatlan álláspontról, gyümölcsözö intuícióról (Sraffa, Kurz) vagy az elosztás analitikus és empirikus tárgyalására alkalmasnak tartott elméleti konstrukció megvédését célzó stratégiákról (Peach) van-e szó? ${ }^{13}$

A fejezet második része, amelyben Ricardo a legtöbb változtatást hajtotta végre, tovább nehezítette akár korabeli olvasói, akár későbbi magyarázói dolgát. Ricardo itt arra akart megoldást találni, hogy miként lehet időben ugyanazt a gazdaságot, térben pedig különböző gazdaságokat összehasonlítani, vagyis érvényes állításokat tenni a

ben: hiábavalóságukat jól mutatja, hogy nincs kettő, amely legalább megközelítőleg azonos eredményre jutott volna (lásd De Quincey [1824/1890] 53. o., Hollander, J. [1910] 82. o.).

${ }^{12}$ Számszerűen ennek hatása szerinte „nem lehet nagyobb 6-7 százaléknál” (Ricardo [2017b] 96. o.). Stigler ennek alapján nevezte Ricardo koncepcióját 93 százalékos munkaérték-elméletnek (Stigler [1958/1965]).

${ }^{13}$ Lásd Hollander, S. [1979] 217. o., Sraffa [1951] XXXVIII-LVI. o., Kurz [2017] 130. o., Peach [1993] 224., 237-238., 282-283. o. 
jövedelemelosztás változásairól. Ehhez az ideális értékmérőre van szükség, vagyis arra az árura, amelynek értéke változatlan, mivel a termelésére fordított munka sem változik, ezért alkalmas a többi áru értékváltozásának kifejezésére. Mivel azonban elfogadta, hogy a jövedelmek változása hat az árarányokra, ezért a változatlan értékmérö fogalmát is át kellett gondolnia.

Utolsó - Abszolút érték és csereérték (Vázlat) címü - írása, amelyet a most megjelent kötet is közöl (Ricardo [2017e]), és annak töredékben maradt kiegészítése azt tanúsítja, hogy egészen haláláig küzdött a problémával anélkül, hogy a maga számára teljesen kielégítő megoldást talált volna. „[U]gyanazokat a nehézségeket látom, mint korábban, és jobban meg vagyok győződve, mint valaha, hogy szigorúan véve a dolog természete miatt nincs az értéknek semmiféle korrekt mértéke, és nem is lehet ilyet kitalálni" - írta élete utolsó levelének befejező soraiban (Ricardo [1951-1973] IX. köt. 387. o.). A makacs keresésben feltehetőleg azok a korabeli természettudományos fejtegetések is ösztönözték, amelyek a távolságmérés etalonját, a ma is használatos métert kívánták meghatározni egy délkör hosszának segítségével. Végül amellett foglalt állást, hogy olyan árut kell használni, amely „,középen áll”, vagyis amelyet a leginkább átlagos munka- és tőkeráfordítással állítanak elő, s így a legkevésbé érzékeny a jövedelemváltozások hatására. Ricardo azért ragaszkodott mégis a változatlan értékméröhöz, mert csak így tudott olyan koherens értékelmélet felállításával próbálkozni, amellyel bizonyíthatja a gabonatörvények káros hatását a brit gazdaságban.

Hiába tudta, hogy - amint korunk egyik vezető neoricardiánus elmélettörténésze, Heinz Kurz írta - „lidércfényt kerget”, mert a termelés változó körülményei és a jövedelemelosztás változó arányai miatt a változatlanság így nem garantálható, mégis kitartott mellette s a munkaérték-elmélet mellett, elutasítva a kereslet-kínálati mechanizmusra (Malthus) vagy a hasznosságra (Say) építő magyarázatokat éppen úgy, mint Adam Smith érvelését a termelési költségekről. (A változó technológiák esetében az indexszámítás jelentette a megoldást, míg a jövedelemelosztás változásainak kiküszöbölésére - legalábbis azok számára, akik elfogadják a változatlan értékmérőn alapuló közelítés szükséges és lehetséges voltát - Piero Sraffa „standard áruja” nyitotta meg az utat; Sraffa [1960/1975] 37. és a következő oldalak.)

Összekapcsolva az érték, a mérés és az elosztás kérdéseit, Ricardo tovább tudott lépni az össztermék alkotórészei és az alapvető jövedelmek viszonyának növekvő gazdaság körülményei közötti vizsgálatához - ez a következő fejezetek témája. A földjáradék egyszerre fontos és kiiktatható tényezö; a jó földek (Ricardo csupán a mezögazdasági termelésben hasznosított földet veszi figyelembe) növekvő szükössége az utoljára művelés alá vont földön csupán a termelés költségeit (beleértve az alkalmazott tőke normálprofitját) fedező hozamot biztosítja, a jobb földeken az alacsonyabb egységköltség miatt különbözeti járadék keletkezik, ami a földbirtokos jövedelme. A tőkefelhalmozás és a népességnövekedés nyomán ezért nő a gabona ára, vagyis a járadék nem a természet bőkezűségét tanúsítja, hanem ellenkezőleg: szűkmarkúságából fakad, nem értékképző tényező, s nem eleme a termelési költségnek, miként Smith ábrázolta, így nem oka, hanem következménye a magas gabonaárnak.

A járadék után a munkabérek értelmezése is kulcsfontosságú volt Ricardo elosztási és növekedési koncepciója számára, mert szüksége volt a fix reálbér feltevésére 
a társadalom tiszta jövedelmének s benne a profitnak a meghatározásához. Ehhez barátja, Malthus népesedési elmélete szolgáltatott alapot, amely a gyorsabb népesedés és a lassabban növekvő élelmiszer-termelés szükségszerü ellentétéből vezette le a nyomor magyarázatát. Ezt elfogadva, Ricardo a természetes munkabért a „munkások összességének” megélhetéséhez és változatlan nagyságban való fennmaradásához elégséges jövedelemként definiálta. Malthus népesedési törvényének elfogadása egyrészt meghatározta álláspontját a korabeli szegényügyi törvényekkel szemben: szorgalmazta eltörlésüket, mivel azok a támogatáson keresztül elösegítették a növekvő szaporodást, így valójában nemcsak a megadóztatott tehetősek, hanem a munkások helyzetét is rontották.

Ricardo azonban olykor - Smith nyomdokait követve - kilépett a malthusi logikából, hangsúlyozva, hogy a munka természetes ára nem egyszer s mindenkorra rögzített, függ „az életmódtól és a szokásoktól”, és olyan esetet is feltételezett, ahol a piaci bérek a gyorsabb felhalmozás okozta nagyobb munkakereslet miatt hosszabb időn át a munka természetes ára fölé kerülnek. Bár ez az érvelés - amelynek egy későbbi fejezetben ellent is mond (lásd Ricardo [2017b] 416. o.) - értékelméleti szempontból aggályos konzisztenciaproblémákhoz vezet, ${ }^{14}$ de a bérelméletből Ricardo számára igazán az volt fontos, hogy megmutassa: fó tétele változatlanul érvényes a többtermékes gazdaságban is. A profitráta és a bér változása fordított viszonyban van egymással, vagyis az élelmiszer-termelés csökkenő hozadéka miatt nő az élelmiszer ára, adott reálbér (és növekvő pénzbér) mellett ezért elkerülhetetlen a járadékok arányának növekedése és a profitráta csökkenése - hosszú távon bekövetkezik a gazdasági stagnálás, nem lesz forrása a megtakarításnak és a tőkefelhalmozásnak.

Ricardo nem tagadta, hogy a mezögazdaságban is van technikai fejlödés, s ez, ha növeli a föld termőképességét, a járadék csökkenéséhez vezet, ám szerinte ez csak átmeneti hatás, mivel - hasonlóan a munkát megtakarító termelékenyebb eljárások alkalmazásához - az élelmiszerek árcsökkenése a népesség növekedésével jár, s így a járadék ismét nőni fog. Bár ez meglehetősen pesszimista jövőkép kontúrjait vetíti az olvasó elé, amit számos interpretátor úgy fogalmazott meg, hogy az iparosodás (vagy korábbi terminológiával „ipari forradalom”) kortársaként Ricardo „nem látott túl a stagnáló állapoton mint a gazdasági fejlődés lehetséges végpontján” (Solow [2010] 1114. o.), de a helyzet ennél árnyaltabb. A logikai konklúzió - mint nála nemegyszer - itt sem volt azonos a tényleges helyzet megítélésével: „,szerencsére progresszív szakaszban vagyunk, és bizalommal nézhetünk egy hosszú prosperáló időszak elé" írta egy levelében 1816-ban (Ricardo [1951-1973] VII. köt. 17. o.), a bérekről szóló 5. fejezet zárószakaszában pedig ez áll: „ha elérnénk a stagnálás állapotát, amitől, bízom benne, még messze vagyunk" (Ricardo [2017b] 148. o.). Vagyis igazat adhatunk Joan Robinsonnak, hogy Ricardo „stagnáló állapota nem egy egyensúlyi helyzet, hanem ijesztő figyelmeztetés" (Robinson [1978] 15. o.).

A gazdasági és technikai fejlődés lehetőségeinek optimista megítélése részben az összkereslet és az összkínálat egyenlöségét állító Say-törvény elfogadásán alapult, ami Ricardo értelmezésében azt jelentette, hogy amíg van profit, vagyis amíg nem

\footnotetext{
${ }^{14}$ Milyen vonzásközpont az, amelytől a piaci ár tartósan eltérhet? (Peach [1993] 10., 103-131. o.)
} 
emészti fel a növekvő járadék, addig mindig van lehetőség a tőke produktív alkalmazására, $s$ túlberuházás, tőkefelesleg vagy általános túltermelés nem lehetséges. Ez az álláspont az úgynevezett „klasszikus dichotómia” feltevéséhez vezet, amely szerint a monetáris tényezők kizárólag az árszínvonalra hatnak, míg a termelés és a foglalkoztatás szintjét a kínálati oldal „reáltényezői” (tőke-, munka- és földráfordítások, technológia stb.) határozzák meg. Jól mutatja a tétel súlyát Ricardo gondolkodásában, hogy könyve előszavában, ahol méltatta Say művét, jelezve ugyanakkor, hogy - akárcsak Smith esetében - számos pontban vele sem ért egyet, azt is szükségesnek látta, hogy külön kiemelje a francia közgazda piacokra vonatkozó, „néhány nagyon fontos alapelvét" (Ricardo [2017b] 72. o.).

Malthusszal folytatott számos vitája közül talán ez - amely a két barátot az általános túltermelés kérdésében állította szembe, $\mathrm{s}$ amelyet Malthus saját „eretneksége” és Ricardo „ortodoxiája” konfliktusaként írt le - vált a legnagyobb jelentőségűvé „a politikai gazdaságtan további történetében”, legalábbis ha elfogadjuk Keynes interpretációját (Keynes [1933/1972] 98. o.). A vita egyik vonulata a korabeli társadalom jellemzőinek szemben álló megítélésén nyugodott: Malthus az elégtelen összkeresletet a munkások szükségképpen korlátozott fogyasztásából vezette le, amit a túlzott mértékben megtakarító tőkések visszafogott kiadásai nem ellensúlyoznak, s ezért nélkülözhetetlennek tartotta az improduktív fogyasztók és társadalmi csoportok szerepét a rendszerben. Ricardo számára ez a legitimáció elfogadhatatlan volt, mert „minden ember szívében el van ültetve a vágy”, hogy többet fogyasszon, ha módja van rá, a rendszer növekedése önfenntartó. Ezért az ő szemében „[a] nem termelő dolgozók rétege pontosan annyira szükséges és hasznos a jövő termelés szempontjából, mint az a tüzvész lenne, amely a gyáros raktárában felemésztené mindazokat az árukat, amelyeket egyébként az improduktív dolgozók fogyasztottak volna el." (Ricardo [1969] 421. o.)

A vita másik rétegét az 1815 utáni konkrét gazdasági helyzet eltérő megítélése gerjesztette. Malthus szerint a „háborúból a békébe történő átmenet” visszatérő nehézségei Angliában, Amerikában, Hollandiában és Németországban nem időszakosak voltak, és nyilvánvalóan mondtak ellent Say és Ricardo elméletének, „a pénzkamat esését és a tőke alkalmazásának nehézségét általánosan elismerik", amire az ő teóriáik „semmiféle elfogadható magyarázatot nem adnak” (Ricardo [1951-1973] VIII. köt. 260. o.). Ricardo válasza ebben csak késedelmes alkalmazkodást és irracionális viselkedést látott, némileg ellentmondva előbb idézett szavainak: „[a]z a nehézség, amelyet Ön említ (...), abból az elóítéletből és makacsságból fakad, amellyel az emberek [tőkéjük] megszokott alkalmazásaihoz ragaszkodnak (...), napról napra azt várják, hogy a dolgok majd jobbra fordulnak, s ezért továbbra is megmaradnak olyan termékek termelése mellett, amelyekre nincs megfelelő kereslet (...). Az emberek tévednek termelésükben, a keresletben nincs hiány." (Uo. 277. o.)

Egyik kommentátora szerint Ricardo a tények alapos ismeretében helyes választ adott: a háború után a brit gazdaság nem került tartós depresszióba, hanem különböző külső sokkok (rossz termés, külkereskedelmi problémák stb.) hatására visszavezethető ingadozásokon ment keresztül, amelyekhez sikeresen alkalmazkodott (Davis [2005] 42. o.). Ez azonban nem jelenti azt, hogy teljesen kizárta volna az általános túltermelés 
átmeneti előfordulását: „a kereskedelem ellanyhulóban - iparűzők és kereskedők mennek csődbe -, a túlkínálat általánossá válik, és minden piacunk túl van telítve jószágokkal (...), de gyorsan vissza fogjuk szerezni megszokott energiánkat és lendületünket $^{\text {"15 }}$ - így jellemezte az aktuális helyzetet egy 1819. áprilisi levelében.

Hasonló optimizmussal tekintett, legalábbis eleinte, a technikai fejlődésre, a gépek alkalmazására, akkor is, ha - mint láttuk - a természeti szükösség, a föld csökkenő hozadéka kérdésében borúlátó maradt. Azt viszont egyértelműnek tartotta, hogy „a gépek tökéletesítésének hatására (...) nő a munka reálbére" (Ricardo [1951-1973] IV. köt. 35. o.), és egy parlamenti felszólalásában is arról beszélt, hogy a gépesítés nem csökkenti a munka keresletét. ${ }^{16}$ Könyve harmadik kiadásához azonban új fejezetet csatolt a gépekről (31. fejezet), s ebben felülvizsgálta, részben visszavonta korábbi véleményét. Továbbra is fenntartotta belőle azt, hogy a gépek alkalmazása miatt nő a társadalom tiszta jövedelme, olcsóbb lesz a termelés, és ez előnyös a tőkések és a földbirtokosok szempontjából, de elismerte, hogy ugyanez a folyamat a munkások egy részét feleslegessé teszi, és rontja helyzetüket.

Nem tudjuk pontosan, hogy mi késztette erre a fordulatra, egy kvéker szerző ellentétes álláspontot képviselő írása-e (Barton [1817]), vagy az események abban az időben, amikor Angliában számos helyen került sor a „ludditák” megmozdulásaira, géprombolásokra. Ám azt tudjuk, hogy amikor ezért az elsőszámú követőjévé és propagátorává szegődő McCulloch szemrehányást tett neki, hogy egyik napról a másikra mintegy behódolt Malthusnak, s ezzel kételyeket ébresztett a tudomány komolysága iránt („sokan azt fogják hinni, hogy a politikai gazdaságtan humbug” (Ricardo [1951-1973] VIII. köt. 382. o.), Ricardo nagyon határozottan válaszolt. Leszögezte, hogy a munkanélküliséget illetően továbbra sem ért egyet Malthusszal, de a gépek alkalmazásának ilyen következménye „,éppolyan bizonyítható igazság, mint a geometria bármely igazsága, s csak azon csodálkozom, hogy olyan sokáig nem vettem észre" (uo. 390. o.). ${ }^{17}$

\section{Ricardo „négy bűvös száma”, „ekvivalenciája” és „vétke”}

Ha van egyetlen olyan elv vagy koncepció, amelyet hallva a mai közgazdászoknak talán még eszükbe jut Ricardo neve, az majdnem biztosan a komparatív előnyök elve, a külkereskedelem elmélete: „az elv, amelyet először világosan Ricardo írt le és bizonyított (...) az egész közgazdaságtan legmélyebb és legszebb eredménye" (Findlay [2008]). Másként szólva, a külkereskedelmet tárgyaló rövid és meglehetősen enigmatikus 7. fejezet, pontosabban az elvet kifejtő első rész állta a legnagyobb sikerrel a sokfelöl érkezö kritikát, a szövetet és bort termelö Anglia és Portugália híres példája, „a négy mágikus szám” (Samuelson) azóta is visszaköszön a tankönyvek lapjairól. Szükséges hangsúlyozni, hogy Ricardót az abszolút kereskedelmi előnyökről szóló

\footnotetext{
${ }^{15}$ Ez a levél nem található meg az összkiadásban (lásd Heertje-Weatherall [1978] 570. o.).

${ }^{16}$ Később erre még visszatérünk.

${ }^{17}$ Lásd erről Berg [1980], különösen 43-74. o.
} 
smithi koncepció továbbfejlesztése ugyanazért érdekelte, mint a gabonatörvény problémája: azokat a módozatokat kereste, amelyek lehetőséget adnak az olcsó bérjavak importjára, feltartóztatva ezzel a profit csökkenését.

Az arbitrázsügyletekkel napi szinten foglalkozó tőzsdés számára könnyü volt belátni, hogy ha Portugáliában a bort és a szövetet is kisebb munkaráfordítással állítják elö, mint Angliában, a két ország között mégis van lehetőség kölcsönösen előnyös specializációra és kereskedelemre. Ha Anglia szövetet exportál, és cserébe bort hoz be Portugáliából, mindkét ország nyer a cserén, mert kisebb ráfordítással jut nagyobb jószágmennyiséghez, mint ha csak maga állítaná elő azt. A fejlettségi különbségből fakadó abszolút előny, illetve hátrány nem akadályozza a kölcsönösen előnyös munkamegosztást, vagyis Ricardo érvelése nemcsak alátámasztotta Smith - az antik ökonómia nyelvét alkalmazó - okfejtését a munkamegosztás és a szabadkereskedelem előnyeiről, hanem ki is bővítette egy alapvető dimenzióval. Minden ország számára nemcsak azokat a javakat előnyös exportálni, amelyeket másoknál olcsóbban állít elő, hanem azokat is, amelyeket a behozott javaknál olcsóbban képes megtermelni, vagyis a nemzetközi kereskedelem mai nyelven szólva: a kimenet minden résztvevő számára pozitív összegü. Természetesen ez csak a fogyasztók szempontjából igaz, hiszen azoknak a termelőknek, akiket az olcsóbb import kiszorít korábbi hazai piacaikról, ebben a minőségükben esetleg nagyobb veszteséggel kell számolniuk, mint amit fogyasztóként nyernek.

A gondolatmenet talán legfontosabb kritikáját azok fogalmazták meg, akik statikus jellegét bírálták: Ricardo itt nemcsak a tőke és a munka áramlását zárta ki, hanem azt is feltételezte, hogy a komparatív előnyök és hátrányok megoszlása adott és változatlan. Mások azt furcsállották, hogy Ricardo egy létfenntartási cikk és egy luxusjószág cseréjét választotta példának, nem pedig a 7. fejezetben szintén említett, „gabonát termesztő Amerika vagy Lengyelország" lett a partner - Joan Robinson ebben retorikai fogást látott: a mindkét termékben termelékenyebbnek feltételezett portugál gazdaság „példája meghökkentö”, és „,rövidre zárja” a gondolatmenetet a hazai termelés védelmét sürgető népszerü érveléssel szemben (Robinson [1974] 4. o.).

Ha azonban figyelembe vesszük a tényleges egyenlőtlenségeket az országok hatalmi helyzetét, érdekérvényesítő képességét, reálbérszintjét stb. illetően, akkor az előnyök megoszlása is igen egyenlőtlen lehet. A 20. vagy a 21. század dilemmáit, az új kereskedelmi elmélet álláspontját tükröző eszmetörténeti olvasatok további részletezése helyett itt inkább arra érdemes felhívni a figyelmet, hogy Ricardo optimista elmélete lényegében ugyanarra az eredményre jutott, mint az előző évszázadban Hume úgymond pesszimista okfejtése a gazdag és szegény országok, Anglia, Skócia és Írország viszonyát és a felzárkózás esélyét elemezve. Vagyis a világméretű szabadkereskedelem nemcsak a fejlett Anglia számára kívánatos, mert a minél távolabbi jövőbe tolja a stagnálás bekövetkeztét, hanem a szegény országoknak is, mert lehetőséget ad a felzárkózásukra. ${ }^{18}$

Szemben a komparatív előnyökről szóló, rövid és nagy hatású levezetéssel, az Alapelvek majd egyharmada az adózást taglalta, részletesen foglalkozott a különböző adók

${ }^{18}$ Hont [2008] 313. o. Modern elméleti és empirikus relevanciájáról lásd még Samuelson [2001], Costinot-Donaldson [2012]. Legújabban Evenett [2017] és Senga és szerzőtársai [2017]. 
jellemzőivel és hatásaival, gyakori kitérőkkel és ismétlésekkel nehezítve az olvasó dolgát, anélkül, hogy a könyv - címének megfelelően - világos alapelveket fogalmazott volna meg ebben a tárgyban, vagy lényeges befolyást gyakorolt volna. Következtetései a korábbi feltevéseiből adódtak: a létminimumon élő munkások bérük után valójában nem fizetnek adót, az adók forrása a földjáradék és a profit. Az egyes adók részleteitől azért is eltekinthetünk, mert Ricardo is ezt tette egyik első parlamenti beszédében: „,az egyes adókat illetően szükségtelen állást foglalnom, mert általában ellensége vagyok az adózásnak" (Ricardo [1951-1973] V. köt. 26. o.). Ez az ellenségesség részben elméleti alapállásából következett, mert a magas adók hátrányosak a tőkefelhalmozásra, részben pedig politikai meggyőződéséből, amely a lakosság töredéke által választott parlamentben és az annak felelős kormányban az oligarchia érdekeinek képviselöit látta. Paradox módon ezért is sürgette azt az egyszeri tőkeadót, amely megszüntette volna az államadósság törlesztési alapját, azaz lehetetlenné tette volna, hogy egy „,arrogánsan és ambiciózusan viselkedő kormány” (uo. 199. o.) visszaéljen vele, ${ }^{19}$ és más kiadásokat fedezzen belőle.

Az államadósságot és a gabonatörvényt tartotta a brit gazdaság két alapbajának, amelyektől megszabadulni „szinte bármekkora áldozatot” megérne, mert akkor „ez lenne a legboldogabb ország a világon, s a prosperitás minden képzeletet felülmúlóan gyarapodna" (uo. 21., 55. o.). Némi vonakodás után, amit elsősorban az indokolt, hogy Ricardo úgy vélte, nincs önálló mondanivalója a kérdésben, 1819-ben mégis megírta az Encyclopaedia Britannica számára az adósságtörlesztésről szóló cikket. Ebben az eredetileg 1716-ban létrehozott és 1786-ban átalakított törlesztési alap felszámolását azzal indokolta, hogy azt a kormányok adósságtörlesztés helyett az aktuális hiány fedezésére használták, „az adósság csökkentése helyett jelentősen növelték azt (...), s a törlesztési alap ösztönözte a kiadásokat" (uo. 195. o.).

Minden adózás makacs ellenfele, aki a parlamentben megszavazta az összes adócsökkentési és ellenezte az összes adóemelési javaslatot, a törlesztési alapot egyszeri vagyonadóval kívánta pótolni, mondván, hogy a kereskedők, földbirtokosok és kötvénytulajdonosok számára azonos, hogy meghatározott átmeneti ideig kell egy magas adót fizetni, és ezzel fokozatosan visszafizetni az államadósságot, vagy meghatározatlan ideig adózni a kamat és az adósságszolgálat terhét fedezve. A javaslat már az 1720 -as években is felmerült, de miként akkor, Ricardo idejében sem aratott sikert: „Félek, hogy a parlamentben az adósság visszafizetésének semmiféle terve sem fog támogatást kapni. Az emberek nem szeretnek azonnali áldozatokat hozni jövendő előnyökért.” A jómódúak ragaszkodnak „képzelt gazdagságukhoz”, pedig a törlesztési alap esetében ez a vagyon csupán képzeletbeli, hiszen a jövedelmet „az adószedőnek kell átadnunk" (uo. 187. o.). Bár Ricardo javaslata pontosan azt a tevékenységet vette célba, amelynek saját vagyonát köszönhette, ráadásul a tervezett adó őt mint földbirtokost és kötvénytulajdonost komoly teherrel sújtotta volna, mégis lemondóan kellett belátnia egy parlamenti beszédében: ezt a javaslatot rajta kívül mindenki képzeletbeli és ijesztő (chimerical) tervnek tartja (uo. 39. o.).

Százötven évvel később Ricardo - immár jelzőként - különös rehabilitációban részesült: Robert Barro a keynesi gazdaságtan ellenében felállította azt a tételt, hogy

\footnotetext{
${ }^{19}$ Ricardo itt a korabeli pénzügyminiszter, N. Vansittart szavain gúnyolódott.
} 
a kormányzatok hiába akarják kötvénykibocsátással finanszírozni a túlköltekezést, és ezzel elkerülni az adóemelések kereslet-visszafogó hatását, mert a háztartások - előre látva a jövőben elkerülhetetlen adóemelést - növelik megtakarításaikat, vagyis az összkereslet változatlan marad (Barro [1974]). James Buchanan, aki egy korábbi könyvében írt arról, hogy Ricardo szerint „az államadósságnak és a rendkívüli adónak ekvivalens hatása van a gazdaságra" (Buchanan [1958] 43. o.), Barro cikkét kommentáló saját írásának címében használta először a kifejezést: Ricardian equivalence (Buchanan [1976] 337. o.).

Noha mindmáig vitatott, hogy a ricardói ekvivalencia empirikusan igazolható-e, hogy életszerüek-e azok a nagyon erős elméleti előfeltevések (teljes informáltság és racionalitás, végtelen időhorizont stb.), amelyek szükségesek a modellben, valamint az is, hogy jogos-e az ő nevéhez kapcsolni a tételt, amikor a képzelt gazdagságról idézett fejtegetése azt mutatja: tudta, hogy a vagyonos emberek egy sajátos fiskális illúzió rabjai (O'Driscoll [1977], Seater [1993], O'Brien [2004], King [2013] 139. o.). Az azonban egyértelmü, hogy Ricardo nem bízott a kormány ellenőrzése alatt lévő pénzek célszerü felhasználásában, így abban sem, hogy a törlesztési alap mérsékli a háború veszélyét: „nincsen erősebb biztosíték a béke fennmaradására, mint az, ha a minisztereknek a néphez kell fordulniuk, és adókat kell kivetniük a háború támogatására" (Ricardo [1951-1973] IV. köt. 197. o.). Elutasította a szegények, vagyis a munkanélküliek foglalkoztatására javasolt közmunkák gondolatát is, „minthogy ezzel ezt a tőkét elvonjuk más alkalmazásoktól, amelyek az egész közösségre nézve legalább ugyanannyira vagy még inkább produktívak lennének. Ha például a tőke egy része az országutakon adna munkát a szegényeknek, ez a tőke biztosan tudna másutt embereket foglalkoztatni. Én minden beavatkozást károsnak tartok." (Uo. VII. köt. 117. o.)

A másik jelzős szerkezet, „a ricardói vétek” az előzőnél jóval kevésbé ismert, de amit az elmarasztaló bélyeget rásütő Schumpeter érzékletessé akart tenni vele, már az első írásoktól kezdve (mint arra a tanulmány elején utaltam) visszatérő mozzanata volt és maradt Ricardo recepciójának: „,a pamflet tisztán elméleti, és ezért nem kielégítő - írta róla az ôt támadó Bosanquet 1810-ben -, mert nem vetették alá a tények próbájának" (Bosanquet [1810] 2. o.). Ricardo erre azzal vágott vissza, hogy a Bosanquet által idézett, az ő érvelésének ellentmondó árfolyamadatok nyilvánvalóan csak hibásak lehetnek, s az, hogy valaki „ilyen tényekkel akar megcáfolni egy elméletet, melynek észszerüsége elfogadott, szomorú bizonyítéka az elöítéletek hatalmának még a legfelvilágosultabb gondolkodók körében is" (Ricardo [1951-1973] III. köt. 181-18. o.).

Schumpeter a ricardói vétket a profitelmélet példáján szemléltette, mert szerinte Ricardo profitmagyarázatában igyekezett minden mást adottnak venni, s így a profit nála nem is függött semmi mástól, vagyis „cáfolhatatlan, ám értelmetlen elméletet” állított fel. „, „A] gyakorlati következtetések súlyos terhét egy bizonytalan alapra építette föl, amely nem volt erre méretezve, de egyszerüsége miatt nemcsak vonzónak, hanem meggyőzőnek is tünt.” (Schumpeter [1954] 473., 1171. o.)

Ricardo meggyőződését ez a kritika aligha rendítette volna meg, hiszen Malthusszal folytatott évtizedes vitájának ez volt az egyik legfontosabb témája: míg barátja „bizonyos változásoknak mindig csak közvetlen és múló hatásait tartja szem előtt 
(...), én viszont a dolgoknak azt a tartós állapotát, amelyet e változások elöidéznek" (Ricardo [1913] 129-130. o., [1951-1973] VII. köt. 120. o.).

Vitatott kérdés, mi állt e módszertani disputa hátterében. Ricardo maga úgy vélte, hogy az egyik ok a politikai gazdaságtan mint tudomány jellegének eltérő megítélése: „Malthus (...) azt mondja, hogy a politikai gazdaságtan nem szigorú tudomány, mint a matematika, és ezért azt gondolja, hogy pontatlanul használhatja a szavakat, időnként más-más jelentést tulajdonítva nekik. Ennél abszurdabb állítást el sem lehet képzelni" - írta James Millnek (Ricardo [1951-1973] VIII. köt. 331. o.). Malthus valóban azzal érvelt, hogy ő „úgy veszi a dolgokat, ahogy vannak, mert ez az egyetlen út ahhoz, hogy valaki írásaival használjon a társadalomnak, és ne essen a laputai szabók hibájába, hogy a kiindulópontban elkövetett kis hiba miatt olyan következtetésekre jusson, amelyek a lehető legtávolabb állnak az igazságtól (...). Bármely szerző olyan hipotéziseket állíthat fel, amilyeneket csak akar, de ha olyasmit tételez fel, ami gyakorlatilag egyáltalán nem igaz, akkor eleve lehetetlenné teszi, hogy ezekből bármilyen gyakorlati következtetést vonjon le.” (Uo. VII. köt. 121-122. o.)

Bármennyire csábító lenne a vita mai aktualitását hangsúlyozni (az áthallást csak erősíti, hogy a válságok kapcsán Malthus, aki anglikán lelkész is volt, a saját álláspontját „eretneknek” nevezte, szemben Ricardo ,igazhitü ortodoxiájával” - uo. VIII. köt. 261. o.), inkább arra a sajátos, már-már paradox vitaszituációra szeretnék rámutatni, hogy a politikai gazdaságtant szigorú, a matematikához hasonló tudományként definiáló Ricardo mủkedvelő természetbúvár és autodidakta elméleti gondolkodó volt, míg a tárgy első angliai professzoraként müködő, matematikából egykor kitűnő eredménnyel végzett Malthus elutasította ezt a definíciót, és amellett tört lándzsát, hogy „a politikai gazdaságtan közelebb áll az erkölcs és a politika tudományához" (Malthus [1827] 2. o.).

\section{A képviselö, „aki egy másik planétáról csöppent ide”}

Ricardo életének utolsó négy esztendejében igen aktív parlamenti képviselő volt, a most megjelent kötetben (Ricardo [2017a]) szereplő két beszéde erről az oldaláról is igyekszik őt bemutatni az olvasónak. Politikai felfogását és tevékenységét a vele foglalkozó irodalom sokáig nem tartotta sem eredetinek, sem különösen érdekesnek, de az elmúlt évtizedekben születtek olyan interpretációk, amelyek úgy ábrázolják, mint eredeti és jelentős politikai gondolkodót, a modern értelemben vett demokratikus berendezkedés szószólóját, aki összeegyeztethetőnek látta a piaci társadalom müködését és az alapvető politikai reformot, a demokratikus képviseleti rendszer megvalósítását (MilgateStimson [1991]). A gond csak az, hogy ezek az értelmezések - a közgazdászok olvasataira rímelve - nem a saját korának fogalomrendszerében rekonstruálják Ricardót, hanem későbbi koncepciók valamilyen előfutáraként (Hont [1994]).

„Tiszteletre méltó barátom (...) úgy érvelt, mintha egy másik planétáról csöppent volna ide, mintha ez a kereskedelem teljes szabadságának országa lenne (...), egy utópikus világ, ahol csak a gabonakereskedelmet korlátozzák" - gúnyolódott Ricardóval a parlamentben az a Henry Brougham (Ricardo [1951-1973] V. köt. 62. o.), aki pedig whig politikusként számos más kérdésben együtt szavazott független 
képviselőtársával, s aki évtizedekkel később emlékirataiban azt írta róla: „bár szélsőséges véleményt képviselt az egyház és az állam alkotmányának reformjáról (...), de kevés embernek volt nagyobb súlya a parlamentben, senki (...), aki általában a hallgatósága érzületei ellen beszélt, nem részesült olyan türelmes, sőt egyetértő figyelemben" (Brougham [1856] 171. o.).

Ricardo a parlamentben elsősorban gazdasági kérdésekben szólalt fel, a szabadkereskedelem, a politikai gazdaságtan és a józan ész nevében foglalva állást, ám olykor ténylegesen alkalmat adva az előbb idézetthez hasonló visszavágásokra. „[A]z igazi politikai gazdaságtan elvei soha sem változtak, akik pedig nem értik ezt a tudományt, jobb, ha hallgatnak róla" - szúrt oda ellenlábasának egy olyan törvény vitájában, amely egy iparágban hatósági bérszabályozást írt elö, amit Ricardo természetesen ellenzett. De nem azért, mintha ő nem rokonszenvezett volna a dolgozó osztályokkal, akiket „a társadalom legértékesebb részének" tartott, hanem mert úgy vélte, hogy a beavatkozás még az ő szempontjukból is káros (Ricardo [1951-1973] V. köt. 296. o.).

Az idézett mondatok 1823 májusában hangzottak el, s némileg ironikus, hogy ugyanebben a hónapban mondta el - a Ricardo [2017a] kötetben szereplö - Az ipari munkások béréről címü beszédét, amely éppen az ő álláspontjának lényeges változását tanúsította, amikor a legfelsőbb politikai fórumon is ellentmondott néhány évvel korábban ott előadott véleményének („,a gépek nem csökkentik a munka iránti keresletet"- uo.), és elismételte az Alapelvek harmadik kiadásában kifejtett gondolatot: a gépek alkalmazása hátrányos a munkásosztályra. Ehhez talán érdemes hozzátenni, hogy Ricardo a gépesítés kapcsán is alkalmazta szokásos reductio ad absurdum típusú érvelését, amit ma sok közgazdász a közeljövő fenyegető perspektívájának lát: „Ha a gépek minden munkát el tudnának végezni, amit ma munkások végeznek el, nem lenne kereslet a munka iránt. Senki nem lenne jogosult semmit sem fogyasztani, aki nem tőkés, és aki nem tud vásárolni vagy bérelni egy gépet." (Ricardo [1951-1973] VIII. köt. 399-400. o.)

A Ricardo [2017a] másik szemelvénye az általa legfontosabbnak tartott politikai témával, a jó kormányzás biztosításához elengedhetetlenül szükségesnek ítélt parlamenti és választójogi reformmal foglalkozó beszédét mutatja be. (Itt kell megjegyezni, hogy a beszédek forrása a korabeli sajtó beszámolója, de szó szerinti jegyzőkönyvek ekkor nem léteztek.) Természetesnek tűnhet, hogy parlamenti felszólalásaiban a politikai témák aránya jóval kisebb volt, mint a gazdaságiaké, de ehhez szükséges hozzátenni, hogy az előbbieknek is nagy jelentőséget tulajdonított: két önálló kéziratban is taglalta a parlamenti reform kérdéseit, és sürgette a titkos szavazás bevezetését. Az egyik, őt búcsúztató újságcikk úgy méltatta parlamenti szereplését, hogy Ricardo „mérsékelt ellenzéki volt (...), ám a leghatározottabb és legkövetkezetesebb reformer (...), aki minden alkalommal a nép mellett szavazott" (idézi Sraffa: uo. V. köt. XIX. o.). Valóban, kiállt a vallás- és véleményszabadságért, a polgári jogokért stb., és ellenezte azokat a korlátozó törvényeket, amelyeket az 1819-es vérbe fojtott manchesteri tüntetést követően hoztak, sőt olykor támogatott olyan elképzeléseket, mint Robert Owen ,jóindulatú terveit” a nyomor orvoslására, annak ellenére, hogy utópikus képzelgésként jellemezte azokat, vagyis álláspontja itt sem volt mindig konzisztens. 
Ricardo számára a nép részvétele választott képviselőin keresztül volt a jó kormányzás szükséges feltétele, „nincs más osztály a közösségben, amelynek érdekei oly világosan a jó kormányzás oldalán vannak - minden más osztálynak lehetnek olyan saját érdekei, amelyek ellentmondanak a nép érdekeinek" (uo. VII. köt. 261. o.). Népen azonban csupán „a lakosság értelmes részét” értette, s rájuk akarta kiterjeszteni a választójogot, s ezért nem támogatta a köztársasági kormányformát, szemben a brit vegyes kormányzattal, és ezért akarta korlátozni az általános választójogot azokra, „akikről nincs ok feltételezni, hogy érdekük a tulajdonjogok felborítása" (uo. VIII. köt. 370. o.).

\section{Ricardo 1817-2017 - a recepció két évszázada}

Az Alapelvek megjelenését követően John Ramsay McCulloch terjedelmes és rendkívül pozitív ismertetést írt róla az Edinburgh Review-ban, amelyben saját korábbi koncepcióit is feladva, minden kérdésben elfogadta Ricardo elméletét, és elsőként fogalmazta meg, hogy e nagyszerü munka szerzője „többet tett a politikai gazdaságtan haladásáért, mint bárki más, talán az egyetlen Adam Smith kivételével” (McCulloch [1818] 60. o.). McCulloch és James Mill („csak Ön és én vagyunk a két igazi tanítványa" ${ }^{\text {"20 }}$ írásai meghatározó szerepet játszottak abban, hogy a következö két évtizedben Ricardo érvelése más koncepciókat háttérbe szorítva, a politikai gazdaságtan tudományos álláspontjaként váljék széles körben ismertté - mint amely választ ad számos alapvetően fontos és aktuális kérdésre. Ehhez persze sokszor le kellett egyszerüsíteni az absztrakt és nehezen követhető eredeti érvelést, amit Jane Marcet ${ }^{21}$ és Harriet Martineau népszerüsítő írásai teljesítettek ki abban a korban, amikor a jobb társaság, vagyis a középosztály „,kékharisnyái között nagy divat volt a politikai gazdaságtan kérdéseiröl beszélgetni”, ${ }^{22}$ ami feltehetően inkább jelentette a szabadkereskedelemmel, a szegénygondozással, a gazdasági individualizmussal stb. kapcsolatos attitüdök elfogadását, mintsem az olykor igen ambivalens elemeket tartalmazó gondolatrendszerben való intellektuális elmélyedést.

Ez az ambivalens fogadtatás azokat a radikális szerzőket jellemezte az 1820-1830as években, akik aktív kifejezői voltak annak a társadalmi elégedetlenségnek, amely a fennálló rendszert a vagyon és a tulajdon egyenlötlensége miatt támadta, szembeállítva vele „a munkás jogát a munka teljes termékére”. E szerzők ugyan semmilyen értelemben nem alkottak iskolát, Herbert Foxwell 1899-ben mégis ricardiánus szocialistáknak nevezte el őket, noha sem az nem állja meg a helyét, hogy mindannyian hivatkoztak volna a klasszikus közgazdászokra és közöttük Ricardóra, valamint az ö értékelméletére (s akik igen, azok sem mindig pozitív értelemben), sem az, hogy valamennyien szocialisták lettek volna (akadt köztük liberális, sőt konzervatív is). Az elnevezés éle Ricardo ellen irányult, aki „bármely szocialista szerzőnél inkább

\footnotetext{
${ }^{20}$ Ezt írta Mill McCullochnak Ricardo halálakor (Ricardo [1951-1973] IX. köt. 391. o.).

${ }^{21}$ Jane Marcet „kiemelkedő közgazdászként” idézte Ricardót könyve ötödik kiadásában (lásd Marcet [1824] 247. o.).

${ }^{22}$ Erről Maria Edgeworth, aki többször volt Ricardo vendége, írt egy találkozásukról beszámoló levelében (Ricardo [1951-1973] X. köt. 172. o.).
} 
rendítette meg annak a társadalomnak az alapjait, amelyet pedig tipikusnak és természetesnek tartott" (Foxwell [1899] XLI-XLII. o.). Foxwell - Anton Menger nyomán - azt állította, hogy Ricardo durva általánosításai a felelősek „a modern szocializmus képzelt tudományos bázisának” kialakulásáért, ő provokálta ki „annak forradalmi formáját" (uo. LXXXIII. o.).

A vád már korábban is megfogalmazódott, Foxwell Toynbeet visszhangozta: „Ricardo még Smithnél is nagyobb hatással volt az emberek gyakorlati müködésére és a társadalmi kérdések elméleti kezelésére. Könyve egyszerre volt nagy támasza és legrettenetesebb fenyegetője a középosztálynak; ez utóbbi azért, mert egyenesen belőle fakadt a szocializmus két nagy tankönyve, Marx Károly Das Kapitalja és Henry George Progress and Povertyje." (Toynbee [1884/1909] 139-140. o. Navratil Ákos fordítását kiigazítottam - M. A.) Nem csoda, hogy jó harminc évvel később Foxwell még arra készült, hogy a Brit Királyi Közgazdasági Társaság elnökeként előadást tartson arról az emberről, ,,aki meggyőzte a világot a tőke és a munka érdekei közötti szükségszerủ ellentét vészterhes eretnekségéről”. Foxwell szemében Ricardo deduktív és tudománytalan hipotézisei készítettek utat „Marx szocializmusának és az osztályharcnak" (idézi Winch [2009] 257. o.). Ám Marx ezt másképp látta: Ricardo egyfelől a munka-értékelmélettel „a polgári rendszer fiziológiájának - belső szerves összefüggése és életfolyamata megértésének - alapzatát" (Marx [1961] II. köt. 148-149. o.) határozta meg, másfelöl viszont ezt az ellentétet „naivul társadalmi természeti törvénynek fogta fel”, amivel „a gazdaságtan polgári tudománya el is érkezett áthághatatlan korlátjához" (Marx [1867/1967] 108. o., lásd Steedman [1982]).

„Ricardo a politikai gazdaságtan absztrakt tudományának alapítója, és írásai (...) mindmáig annak legtisztább forrásait jelentik. Amit azóta hozzáadtak a tudományhoz, nem kell helyettesítenie, csak kiegészítenie az ő tanait. Nem kíván változtatást vagy helyesbítést, csak teljesebb kifejtést és kommentárt." (Mill [1845/2006] 394. o.) Ez volt John Stuart Mill véleménye, és az 1848-ban megjelent könyve (Principles of Political Economy), a klasszikus politikai gazdaságtan időben harmadik fö müve igyekezett is megfelelni e programnak, pozitívabb és optimistább formában újrafogalmazni Ricardo gazdaságtanát, ami azt is jelentette, hogy Ricardo hatása további évtizedekig is jelentős maradt a brit közgazdaságtanban, annak ellenére, hogy dominanciáról az 1840-es évek óta már nem megalapozott beszélni. A határhaszon-elmélet színre lépése az 1870-es években fokozatosan átrendezte a közgazdaságtan prioritásait: az érték és a makrogazdaság növekedésének klasszikus problémáját a szubjektív hasznosság, a mikroökonómiai döntések, az erőforrások hatékony alkalmazásának kérdésköre váltotta fel. A marginális forradalom egyik alapító figurája, Jevons ezt az új elméletet Ricardo ellenében fogalmazta meg, ${ }^{23}$ homályban hagyva, hogy saját járadék- és tökeelmélete milyen mértékben kötődik nevezetes elödjéhez.

Vele ellentétben Marshall a brit elméleti hagyomány kontinuitását igyekezett hangsúlyozni, Ricardót - John Stuart Mill véleményét visszhangozva - az absztrakt

\footnotetext{
${ }^{23}$ Jevons nem ismerhette Malthus korábban idézett véleményét, de szinte szó szerint ugyanazt vetette Ricardo szemére: „Ricardo, ez a tehetséges, de fonák gondolkodású ember rossz útra vitte a közgazdaságtan szekerét." (Jevons [1871/1970] 72. o.)
} 
ökonómia egyik megalapítójának nevezte, és védelmébe vette őt mind a neoklasszikus kritikákkal, mind az értékelmélet radikális és szocialista interpretátoraival, így Marxszal szemben. Marshall nemcsak védelmébe vette Ricardót Jevons azon vádja ellen, hogy értékelméletével rossz irányba térítette a közgazdaságtant, és figyelmen kívül hagyta a kereslet szerepét, de azt is tudni vélte, hogy mi okozta Ricardo módszertani tévedését - a származása. Szerinte „Ricardo elmélete a termelési költség és az érték viszonyáról olyan fontos helyet foglal el a közgazdaságtan történetében, hogy valódi jellegének bármely félreértelmezése szükségképp káros; de sajnos oly módon fejtette ki, ami szinte invitálja a félreértéseket" (Marshall [1890/1972] 416-417. o.).

Szemben a széles körben elfogadott nézettel, Marshall nem látta szükségesnek az elmélet rekonstrukcióját, „ellenkezőleg, az elmélet alapjai, abban a formában, ahogy Ricardo hagyta őket, változatlanok maradtak; sok mindennel egészítették ki (...), de nagyon keveset vettek el belőle" (uo.). Azzal a váddal viszont, hogy Ricardo absztrakciói figyelmen kívül hagyták az emberi viselkedést befolyásoló történeti és intézményi körülményeket, Marshall egyetértett. „Az érvelés egyszerüsége kedvéért Ricardo és követői gyakran úgy beszéltek, mintha az embert állandó mennyiségnek tekintenék, és sohasem törődtek azzal, hogy változásait figyelembe vegyék. Ök emberként legjobban a városlakókat ismerték", és ugyanúgy lényegtelennek tekintették más emberek és nemzetek jellemzőit, mint az angol jogászok, akik „a hindukra erőltették a brit törvényeket" (uo. 630. o.).

Noha ez az érvelés a 19. század elejének angol birodalmi elitjében uralkodó általános felfogás elmarasztalásaként olvasható, Marshall indoklása egészen más okra vezette vissza Ricardo hibáját: „Gyakran úgy beszélt, mint egy reprezentatív angol: pedig éppenséggel nem volt az. Erőteljes alkotó eredetisége minden nemzetben a legmagasabb rendü géniusz ismertetőjegye. De az indukció iránti ellenszenve és az absztrakt érvelésben talált öröme nem az angol oktatásnak, hanem - miként Bagehot rámutatott - szemita eredetének köszönhető. A szemita faj csaknem minden ágának különleges képessége van az absztrakciókra, és közülük sokan elöszeretettel viseltetnek a pénzüzlettel és annak modern fejlődésével járó absztrakt kalkulációk iránt (...), de még az angol embernek is nehéz Ricardo útját követni, külföldi kritikusai pedig általában nem tudták megtalálni müvének igazi irányát és célját." (Uo. 629. o.)

Zárójelbe téve Marshall szövegének nyilvánvaló ambivalenciáját - egyszerre tette meg Ricardót a marginalizmus kiemelkedő előfutárának, és alkalmazta rá (Bagehot nyomdokait követve, Bagehot [1880] 152-153. o.) a fin du siécle antiszemita kliséit -, az igazi kérdés a Ricardo-paradoxon, amit Winch nyomán már korábban szóba hoztam. Hogyan lett egy ilyen nehezen befogadható könyv rendkívül befolyásos és sikeres a korabeli Nagy-Britanniában és azon túl, mi tette hatását tartóssá, miért vált Adam Smith mellett a töle annyira különbözö Ricardo a klasszikus közgazdaságtan másik ikonikus figurájává - pozitív és negatív értelemben egyaránt? Egymás mellé rakosgatva a recepciótörténet néhány cseréptöredékét, ${ }^{24}$ ha a miért kérdésére nem is fogunk tudni meggyőző választ találni, talán közelebb kerülünk a hogyan megértéséhez.

\footnotetext{
${ }^{24}$ Hasznos támpontokat ad ehhez a kontinentális Európa és Japán tekintetében FaccarelloIzumo [2014].
} 
Marshall leghíresebb tanítványa, John Maynard Keynes az 1930-as években további változattal gazdagította a valóságos elemeket fiktív mozzanatokkal ötvöző Ricardo-interpretációk addigi variációit. Ellenkezőjére fordítva mestere következtetését, azt állította, hogy a hatékony kereslet elvének kiiktatásával Ricardo egy évszázadra teljes győzelmet aratott a közgazdaságtanban, és „teljes dominanciája egy százéves időszakon keresztül katasztrófát jelentett a közgazdaságtan haladása szempontjából" (Keynes [1933/1972] 89. o.). Milyen más lett volna a lehangoló tudomány (dismal science) további sorsa, ha nem Ricardo, hanem Malthus lett volna az ortodoxia szülőatyja, „mennyivel gazdagabb és bölcsebb hely lenne ma a világ” (uo. 100. o.). A General Theoryben ehhez azt is hozzátette: e győzelem magyarázata abban keresendő, hogy „a hatalom birtokosainak kapóra jött, mert sok társadalmi igazságtalanságot (...) a haladással járó elkerülhetetlen bajnak tüntetett fel” (Keynes [1936/1965] 52. o.). Így következhetett be az az állapot, hogy az összkereslet szerepét tagadó Ricardo egy évszázadra „olyan tökéletesen meghódította Angliát, mint annak idején a Szent Inkvizíció Spanyolországot. Nemcsak hogy elfogadta elméletét a City, az államférfiak és a tudományos világ, hanem a vita is megszűnt." (Uo.) (Zárójelben: Keynes utalása az inkvizícióra finoman szólva nem volt szerencsés egy olyan szerző kapcsán, akinek ősei az inkvizíció elől menekültek el az Ibériaifélszigetről, s aki a lelkiismereti és vallásszabadság korlátozását éles szavakkal utasította vissza a parlamentben, mert egy szabad országban az „túlságosan emlékeztet az inkvizícióra" - Ricardo [1951-1973] V. köt. 280. o.)

Az ellentmondó interpretációk tarka 19. századi kavalkádját újabbakkal megtetéző 20. századi értelmezésekből nagyjából három vonulat rajzolódik ki (King [2013] 186-208. o.). Az elsőnek, amely formalizálni törekszik Ricardo szigorú közgazdaságtanát, szintén vannak 19. századi előzményei, hiszen erre az első kísérletek már az 1830-as években megtörténtek Angliában. Whewell, Dmitriev és Bortkiewicz írásait követően a sort többek között Kaldor, Samuelson, Morishima, Pasinetti és mások folytatták (Whewell [1831], Dmitriev [1898/1974], Bortkiewicz [1906-1907], Káldor [1989], Samuelson [2015], Morishima [1989], Pasinetti [1960]). Szükséges hozzátenni, hogy ezek a formalizált interpretációk nem fakadtak közös tőről: Kaldor vagy Pasinetti posztkeynesiánus elosztási modelljei éppen azzal a felfogással szálltak szembe, amelyet a neoklasszikus posztulátumokat elfogadó interpretációk magukénak vallottak.

Csupán röviden illusztrálva: Kaldor szerint a klasszikus közgazdászok a marginális elvet csak a földjáradék esetében alkalmazták, míg Morishima úgy fogalmazott: „Ricardo közgazdaságtana a marginalizmuson alapul (...) ô az előfutára, ha nem az alapítója az általános egyensúlyelméleti iskolának" (Morishima [1989] 149. o.). Sajátos változatot képviselnek ebben a vonulatban Samuelson tanulmányai, amelyek a múltat a jelen előfutáraként rekonstruáló whig történetírás szellemében egy lineáris programozási feladat szabatos modern formuláiban mutatják be a gyakran inkonzisztens és önmagukat sem értő klasszikus közgazdászokat. Ricardo vitája Smith értékelméletével „a modernek számára nem szól semmi lényegesröl”, avagy Malthusszal: elméleti rendszerük (a Say-törvénytöl eltekintve) izomorf, „bár ők úgy gondolták, hogy különböző és össze nem egyeztethetö felfogást képviselnek a mikroökonómiáról" 
(Samuelson [2015] 110. o.). ${ }^{25}$ A neoklasszikus folyamatosság marshalli tézisének legmarkánsabb modern szószólója Samuel Hollander, szerinte „nincs akkora ellentét Ricardo és a neoklasszikus eljárásmód között, amely indokolná, hogy a 19. századi gondolat két elkülönült ágáról beszéljünk (...) osztoznak azon a közös örökségen vagy »központi magon «, ami nagyjából az allokáció elméletét és a kereslet-kínálati elemzés mechanizmusát jelenti” (Hollander, S. [1979] 683-684. o.).

A második az úgynevezett neoricardiánus irányzat, amely a Sraffa-féle összkiadás (Ricardo [1951-1973]) és az 1960-ban megjelent Sraffa-könyv (Sraffa [1960/1975]) nyomán úgy véli, hogy ez újrafogalmazta az érték és elosztás klasszikus felfogását, felhasználva annak erösségeit, és kiküszöbölve a gyenge pontokat. A neoklasszikus olvasatokkal szemben itt Ricardo „rehabilitálása” egy olyan hagyomány feltámasztásába illeszkedik, amely a mainstream ellenlábasaként fogalmazza meg önmagát. A kapitalista gazdaság klasszikus ábrázolásának döntő pontja eszerint az, hogy a profit és a tulajdonosi jövedelmek forrása a többlettermék, s hogy az elosztás változói nem kezelhetők szimmetrikusan: az egyik, a bér kívülről határozódik meg, míg a másik, a profit reziduum. Az erről folyó viták egyik markáns álláspontja szerint ez a Marxon át Sraffához és mai követőihez vezető „többlet”-tradíció sikeres kritikája a neoklasszikus felfogásnak, erőteljes és müködő alternatívát kínál annak kereslet-kínálati elemzésével szemben, noha kiiktatja Ricardo alaptételét az árak és a termeléshez szükséges munkaidő összefüggéséről (lásd King [2013] 201-208. o., Mongiovi [2015] 431-439. o., Kurz-Salvadori [2016] II. 416-429. o.).

A harmadik vonulat az előbbi kettőt Ricardo kisajátítására irányuló kísérleteknek látja, amelyek ugyan tartalmaznak igazságelméleteket, és néhány ponton van hivatkozási alapjuk az eredeti szövegekben, de egészében véve egyik sem tartható. A történeti Ricardót nem szabad összekeverni az „általános egyensúlyelméletet” alapító, kitalált névrokonával, „Ricardo a szó semmilyen ismert értelmében nem volt neoklasszikus”. Ám ez nem ok örömre a másik oldalon, hiszen, akárcsak a neoklasszikusok, Sraffa követői is előfutárt csináltak Ricardóból. Ez azért vezet vakvágányra, mert Sraffa interpretációjának alapproblémája abból fakad, hogy többet olvas bele magából Ricardóba, mint ami jogos, a gabonamodellel „a saját képmására teremti újra Ricardót”, alábecsülve az eredeti írások „összetettségét és zavarosságát” (Peach [1993] 38., 299. o.).

Végezetül szót kell ejteni még arról is, hogy Ricardo származása és vallási kérdésekben tanúsított magatartása is - legalábbis részben - új megvilágításba került az utóbbi esztendőkben. Arnold Heertje pozitívra váltva a korábbi negatív elöjelet, nyomatékosan érvelt amellett, hogy Ricardo intellektuális teljesítménye nem választható el a zsidó háttértől, a Talmud ismeretétől, az örökölt tőzsdei tapasztalattól, amely implicite feltételezi a modellben való gondolkodást. „Megjegyzendő, hogy Ricardo tudományos hozzáállása és véleménye nagymértékben megegyezik Spinozáéval." (Heertje [2004] 292. o.) Sergio Cremaschi viszont azt állítja, Ricardóra jelentős befolyást gyakorolt az az unitárius gyülekezet, amelynek istentiszteleteit rendszeresen látogatta, s amelynek antidogmatizmusa nemcsak a korlátlan, az ateistákat is magában foglaló vallási tolerancia hirdetésében

\footnotetext{
${ }^{25}$ A Samuelson [2015] kötet idevágó tanulmányai a klasszikus politikai gazdaságtan kanonikus modelljéről, a ricardói gazdaság modern ábrázolásáról és a gépesítés hatásáról szólnak.
} 
érvényesült nála, hanem mindenfajta teológiai spekuláció elutasításában, beleértve a politikai gazdaságtan tárgyát és módszerét illető elképzeléseket. Az erkölcsi tudást szkeptikusan szemlélte, s ezért akarta szigorú tudománnyá tenni a politikai gazdaságtant, ezért nem fogadta el sem „Malthus erkölcsi és politikai tudományát, sem James Mill dogmatikus laissez-faire metafizikáját" (Cremaschi [2017] 806. o.). ${ }^{26}$

Ezek az eszmetörténeti pengeváltások a maguk paradox módján támasztják alá az olykor már mitikus figuraként ábrázolt Ricardo relevanciáját - azt, hogy a „közgazdászok közgazdásza” (Samuelson) valóban kimagasló szellem volt, akinek műve két évszázad múltán is képes élénk vitákra sarkallni, a neki tulajdonított jótékony vagy káros befolyással formálni későbbi generációk gazdasági gondolkodását. Noha a kor és az ország, amelyben élt, egy még javarészt agrártársadalomban kibontakozó iparosodás és gazdasági növekedés világa, amelyben hatalmas vagyoni és jövedelmi különbségek jellemezték a társadalmi osztályok viszonyát, ahol a kvázidemokratikus parlamenti rendszer a társadalom töredékének adott lehetőséget a politikai érdekérvényesítésre és az oligarchikus járadékvadászatra, stb. - ez a Nagy-Britannia a számtalan különbség ellenére, amely a mai kapitalizmus(ok)tól elválasztja, mégis olyan anyagot szolgáltatott a gyakorlati kérdésekből kiinduló, de szigorú elméleti logikával érvelő Ricardo számára, amely képessé tette őt a kapitalista gazdaság alapvető összefüggéseinek elemzésére. Műve ezért válhatott egyenrangúvá a 18-19. századi politikai gazdaságtan nagy klasszikus kánonjának többi alkotásával: Adam Smith, John Stuart Mill és Karl Marx könyveivel - annak ellenére és éppen azért, mert számos tekintetben markánsan különbözött is ezektől. Ricardót elfogulatlan és makacs igazságkereső szenvedély jellemezte, ahogy Maria Edgeworth írta róla: „Még sohasem vitatkoztam vagy érveltem senkivel, aki nála korrektebben érvelt volna, akinek ilyen fontos volt az igazság, és ilyen kevéssé fontos a győzelem. Minden vele szemben felhozott érvet teljes súlya szerint mérlegel, és egy perccel sem tart ki tovább valami mellett, mint ameddig meg van győződve annak helytálló voltáról. Számára közömbös, hogy te találod-e meg az igazságot, vagy ö, feltéve, hogy sikerül megtalálni." (Ricardo [1951-1973] X. köt. 169. o.)

\section{Hivatkozások}

Arnon, A. [2011]: Monetary Theory and Policy from Hume and Smith to Wicksell. Cambridge University Press, Cambridge.

BAGeHOt, W. [1880]: Ricardo. Megjelent: Economic Studies. Longmans, London, 151-160. o. BARING, F. [1801]: Observations on the Publication of Walter Boyd. Lane, London.

BARro, R. [1974]: Are government bonds net wealth? Journal of Political Economy, Vol. 82.

No. 6. 343-349. o. https://doi.org/10.1086/260266.

\footnotetext{
${ }^{26}$ Ehhez azért hozzá kell tenni, hogy amikor Ricardo a parlamentben a vallásszabadságot védelmezte, előtte felszólaló képviselőtársa W. Wilberforce - a rabszolga-kereskedelem elleni harc vezéralakja, aki evangéliumi keresztény volt - ezt írta naplójába: „Reméltem, hogy Ricardo keresztény lett; most látom, hogy csak megszűnt zsidó lenni.” (Ricardo [1951-1973] V. köt. 280. o.) A zsidóság és a gazdaságtörténet, illetve a gazdasági gondolkodás kapcsolatát elemző modern tanulmányok sem látnak alapvető összefüggést Ricardo elmélete és származása között (lásd például Penslar [2001] 51.o.).
} 
BARton, J. [1817]: Observations on the Condition of the Labouring Classes. Arch, London.

Beauregard, P. [1889]: Introduction. Megjelent: Ricardo, D.: Rente, salaires et profits. Traduction rev. par M. Formentin. Guillaumin, Párizs.

Berg, M. [1980]: The Machinery Question and the Making of Political Economy 1815-1848. Cambridge University Press, Cambridge, https://doi.org/10.1017/cbo9780511560330.

BharadwaJ, K. [1988]: Sraffa's Ricardo. Cambridge Journal of Economics, Vol. 12. No. 1. 67-84. o. https://doi.org/10.1093/oxfordjournals.cje.a035050.

Blaug, M. [1958]: Ricardian Economics: A Historical Study. Yale University Press, New Haven.

Blaug, M. [1995]: Economic Theory in Retrospect. Cambridge University Press, Cambridge.

Bonar, J. [1911]: Where Ricardo succeeded and where he failed. The American Economic Review, Vol. 1. No. 2. 85-96. o.

BortKiewiCZ, L. von [1906-1907]: Wertrechnung und Preisrechnung im Marxschen System: Eine Übersicht über die Marx-Kritik. Archiv für Sozialwissenschaft, Vol. 23. 1-50. o., Vol. 25. 10-51., 445-480. o.

Bosanquet, C. [1810]: Practical Observations on the Report of the Bullion-Committee. Richardson, London.

Boyd, W. [1801]: A letter to the Right Honourable William Pitt, on the Influence of the Stoppage of Issues in Specie at the Bank of England; on the Prices of Provisions, and Other Commodities. Wright, London.

Brougham, H. [1856]: Mr. Ricardo. Megjelent: Historical sketches of statesmen who flourished in the time of George III. Griffin, London, Vol. II. 166-171. o.

Buchanan, J. [1958]: Public Principles of Public Debt. Irwin, Homewood.

Buchanan, J. [1976]: Barro on the Ricardian equivalence theorem. Journal of Political Economy, Vol. 84. No. 2. 337-342. o. https://doi.org/10.1086/260436.

Caravale, G.-Tosato, D. [1980]: Ricardo and the Theory of Value, Distribution and Growth. Routledge, London.

Churchman, N. [2001]: David Ricardo on Public Debt. Palgrave Macmillan, Basingstoke.

Costinot, A.-Donaldson, D. [2012]: Ricardo's Theory of Comparative Advantage: Old Idea, New Evidence. American Economic Review, Papers \& Proceedings, Vol. 102. No. 3. 453-458. o. https://doi.org/10.1257/aer.102.3.453.

Cremaschi, S. [2017]: Theological themes in Ricardo's papers and correspondence. The European Journal of the History of Economic Thought, Vol. 24. No. 4. 784-808. o. https://doi. org/10.1080/09672567.2017.1315954.

Cremaschi, S.-DAscal, M. [1996]: Malthus and Ricardo on economic methodology. History of Political Economy, Vol. 28. No. 3. 475-511. o.

Davis, T. [2005]: Ricardo's Macroeconomics: Money, Trade Cycles and Growth. Cambridge University Press, Cambridge, https://doi.org/10.1017/s0022050706220242.

De Boyer des Roches, J.-Solis Rosales, R. [2016]: Bullionist and antibullionist schools. Megjelent: Faccarello-Kurz (szerk.) [2016] 167-179. o.

De Quincey, T. [1821/1983]: Egy angol ópiumevő vallomásai. Ford. Tandori Dezső. Európa, Budapest.

De Quincey, T. [1824/1890]: Dialogues of Three Templars on Political Economy. Megjelent: Masson, D. (szerk.): The Collected Writings of Thomas De Quincey. Vol. IX. Black, Edinburgh, 37-112. o.

Deleplace, G. [2015]: Papers on Money and Banking. Megjelent: Kurz-Salvadori (szerk.) [2015] 387-395. o. 
Dixon, W. [2008]: Ricardo: Economic thought and social order. Journal of the History of Economic Thought, Vol. 30. No. 2. 236-253. o. https://doi.org/10.1017/s1042771608000203.

Dmitriev, V. K. [1898/1974]: Economic Essays on Value, Competition and Utility. Cambridge University Press, Cambridge.

Dorfman, R. [1989]: Thomas Robert Malthus and David Ricardo. Journal of Economic Perspectives, Vol. 3. No. 3. 153-164. o.

Eatwell, J. [1975]: The interpretation of Ricardo's Essay on Profits. Economica, Vol. 42. 182-187. o.

Evenett, S. (szerk.) [2017]: Cloth for Wine? The Relevance of Ricardo's Comparative Advantage in the 21st Century. CEPR Press, London.

Faccarello, G.-Izumo, M. (szerk.) [2014]: The Reception of David Ricardo in Continental Europe and Japan. Routledge, Abingdon-New York.

Faccarello, G.-Kurz, H. (szerk.) [2016]: Handbook on the History of Economic Analysis. Vol. I-III. Edward Elgar, Cheltenham.

Findlay, R. [2008]: Comparative advantage. Megjelent: Durlauf, S.-Blume, L. (szerk.): The New Palgrave Dictionary of Economics. Palgrave Macmillan, Basingstoke and New York.

Foxwell, H. [1899]: Introduction to A. Menger: The Right to the Whole Produce of Labour. London, Macmillan.

FöLDES BÉLA [1919]: Ricardo, különös tekintettel a háborús közgazdaság kérdéseire. Értekezések a philosophiai és társadalmi tudományok köréből, Magyar Tudományos Akadémia, Budapest.

Gehrke, C.-Kurz, H. [2002]: Keynes and Sraffa's “Difficulties with J. H. Hollander”. The European Journal of the History of Economic Thought, Vol. 9. No. 4. 644-671. o. https:// doi.org/10.1080/0967256021000024673.

Hagemann, H. [2015]: General Glut. Megjelent: Kurz-Salvadori (szerk.) [2015] 160-169. o.

Hawtrey, R. [1919]: Currency and Credit. Longmans, London.

Heertje, A. [2004]: The Dutch and Portuguese-Jewish background of David Ricardo. The European Journal of the History of Economic Thought, Vol. 11. No. 2. 281-294. o. https:// doi.org/10.1080/0967256042000209288.

Heertje, A.-Weatherall, D. [1978]: An unpublished letter of David Ricardo to Thomas Smith of Easton Grey. Economic Journal, Vol. 88. 569-571. o. https://doi.org/10.2307/ 2232055.

Henderson, J. [1997]: The Life and Economics of David Ricardo. Kluwer, Boston.

Hollander, J. [1910]: David Ricardo, a Centenary Estimate. Johns Hopkins Press, Baltimore.

Hollander, S. [1979]: The Economics of David Ricardo. University of Toronto Press, Toronto.

Hollander, S. [1995]: Ricardo, the New View: Collected Essays. Routledge, London and New York.

Hont, I. [1994]: Review of Ricardian Politics by M. Milgate and S. Stimson. Political Theory, Vol. 22. No. 2. 339-343. o.

Hont, I. [2008]: „The Rich Country - Poor Country” Debate Revisited. Megjelent: Wennerlind, C.-Schabas, M. (szerk.): David Hume's Political Economy. Routledge, Abingdon, 243-323. o. Jevons, W. [1871/1970]: The Theory of Political Economy. Penguin, Harmondsworth.

KÁLDOR MikLós [1989]: Gazdaságelmélet, gazdaságpolitika. Közgazdasági és Jogi Könyvkiadó, Budapest.

Keynes, J. M. [1933/1972]: Malthus. Megjelent: Essays in Biography. Collected Works of J. M. Keynes. Macmillan, London, Vol. X. 71-108. o. 
Keynes, J. M. [1936/1965]: A foglalkoztatás, a pénz és a kamat általános elmélete. Közgazdasági és Jogi Könyvkiadó, Budapest.

KInG, J. [2013]: David Ricardo. Palgrave Macmillan, London.

Kurz, H. [2003]: The Surplus Interpretation of the Classical Economists. Megjelent: Samuels, W.-Biddle, J.-Davis, J. (szerk.): A Companion to the History of Economic Thought. Blackwell, Oxford, 167-183. o.

Kurz, H. [2016]: David Ricardo. Megjelent: Faccarello-Kurz (szerk.) [2016] 120-143. o.

Kurz, H. [2017]: Is there a „Ricardian Vice”? Journal of Evolutionary Economics, Vol. 27. No. 1. 91-114. o. https://doi.org/10.1007/s00191-016-0468-2.

Kurz, H.-Salvadori, N. (szerk.) [2015]: The Elgar Companion to David Ricardo. Edward Elgar, Cheltenham, https://doi.org/10.4337/9781784715489.

Kurz, H.-Salvadori, N. [2016]: Neo-Ricardian economics. Megjelent: Faccarello-Kurz [2016] Vol. II. 416-429. o.

LÁNG Lajos [1891]: A fordító előszava. Megjelent: Ricardo, D.: A közgazdaságtan és adózás alapelvei. Pallas, Budapest, V-X. o.

Malthus, T. [1815]: The Grounds of an Opinion on the Policy of Restricting the Importation of Foreign Corn. Murray, London.

Malthus, T. [1820]: Principles of Political Economy Considered with a View to their Practical Application. Murray, London.

Malthus, T. [1827]: Definitons in Political Economy. Murray, London.

Marcet, J. [1824]: Conversations on Political Economy. Longman, London.

Marshall, A. [1890/1972]: Principles of Economics. Macmillan, London.

MarX, K. [1848/1959]: Beszéd a szabadkereskedelem kérdéséről. In: Marx-Engels Művei. Kossuth, Budapest, 4. köt. 422-436. o.

Marx, K. [1867/1967]: A tőke. I. köt. Marx-Engels Müvei, Kossuth, Budapest, 23. köt.

Marx, K. [1961]: Értéktöbblet-elméletek. II. köt. Kossuth, Budapest.

McCulloch, J. [1818]: On Principles of Political Economy and Taxation by D. Ricardo. The Edinburgh Review, Vol. 30. 59-87. o.

McCulloch, J. [1846/1891]: Ricardo élete és művei. Megjelent: Ricardo, D.: A közgazdaságtan és adózás alapelvei. Pallas, Budapest, XI-XXXIV. o. Eredetileg: A Notice of the Life and Writings of the Author. Megjelent: The Works of David Ricardo. Murray, London. XV-XXXIII. o.

Milgate, M.-Stimson, S. [1991]: Ricardian Politics. Princeton University Press, Princeton.

Mill, J. S. [1845/2006]: De Quincey’s Logic of Political Economy. Megjelent: Collected Works. University of Toronto Press, Toronto, Vol. IV. 391-404. o.

Mokyr, J. [2009]: The Enlightened Economy. Yale University Press, New Haven.

Mongiovi, G. [2015]: Recent Interpretations. Megjelent: Kurz-Salvadori (szerk.) [2015] 431-439. o.

Morishima, M. [1989]: Ricardo’s Economics. Cambridge University Press, Cambridge.

N. N. [1817]: Ricardo and Say on Political Economy. The British Review, and London Critical Journal, 309-333. o.

O’Brien, D. [2004]: The Classical Economists Revisited. Oxford University Press, Oxford.

O'Driscoll, G. [1977]: The Ricardian non-equivalence theorem. Journal of Political Economy, Vol. 85. No. 1. 207-210. o. https://doi.org/10.1086/260552.

PasinetTi, L. [1960]: A mathematical formulation of the Ricardian system. Review of Economic Studies, Vol. 27. No. 2. 78-98. o. https://doi.org/10.2307/2296129.

PeACH, T. [1993]: Interpreting Ricardo. Cambridge University Press, Cambridge. 
Peach, T. [2008]: Ricardo, David (1772-1823). Megjelent: Durlauf, S.-Blume, L. (szerk.): The New Palgrave Dictionary of Economics. Palgrave Macmillan, Basingstoke-New York. Penslar, D. [2001]: Shylock's Children. Economics and Jewish Identity in Modern Europe. University of California Press, Berkeley.

Pollit, B. [1988]: The collaboration of Maurice Dobb in Sraffa's edition of Ricardo. Cambridge Journal of Economics, Vol. 12. 55-65. o. https://doi.org/10.1093/oxfordjournals. cje.a035049.

RICARDo, D. [1815/1951]: An Essay on the Influence of a Low Price of Corn on the Profits of Stock. Megjelent: Ricardo [1951-1973] IV. köt. 1-41. o.

RiCARDO, D. [1891]: A közgazdaság és adózás alapelvei. Ford. Láng Lajos. Pallas, Budapest.

RiCARDo, D. [1913]: Levelek Malthushoz. Ford. Jónás János és gr. Esterházy Mihály. Grill Károly, Budapest.

Ricardo, D. [1940]: A közgazdaság és adózás alapelvei. Ford. Kislégi Nagy Dénes. Magyar Közgazdasági Társaság, Budapest.

Ricardo, D. [1951-1973]: The Works and Correspondence of David Ricardo. Szerk. Sraffa, P. (Dobb, M. közreműködésével). I-XI. köt. Cambridge University Press, Cambridge.

RicARDo, D. [1954]: A politikai gazdaságtan és az adózás alapelvei. A fordítást átdolgozta Bilek Rudolf. Akadémiai Kiadó, Budapest.

RicArdo, D. [1969]: Megjegyzések Malthus „A politikai gazdaságtan elvei” című művéhez. Ford. Rácz Jenő. Akadémiai Kiadó, Budapest.

RicARDo, D. [1991]: A politikai gazdaságtan és az adózás alapelvei. Ford. Kislégi Nagy Dénes, a fordítást átdolgozta Bilek Rudolf. Közgazdasági és Jogi Könyvkiadó, Budapest.

RICARDO, D. [2017a]: A politikai gazdaságtan és az adózás alapelvei. Válogatás egyéb írásokból és parlamenti beszédekből. Ford. Atkári János. Napvilág Kiadó, Budapest.

Ricardo, D. [2017b]: A politikai gazdaságtan és az adózás alapelvei. Megjelent: Ricardo [2017a] 71-435. o.

RICARDO, D. [2017c]: A tömbnemesfém magas ára - a bankjegyek leértékelődésének bizonyítéka. Megjelent: Ricardo [2017a] 437-478. o. Angolul: The High Price of Bullion, a Proof of the Depreciation of Bank Notes. John Murray, London, 1810.

RiCARDo, D. [2017d]: Egy nemzeti bank terve. Megjelent: Ricardo [2017a] 479-493. o. Angolul: Plan for the Establishment of a National Bank, London, John Murray, 1824.

RicARdo, D. [2017e]: Abszolút érték és csereérték (Vázlat). Megjelent: Ricardo [2017a] 494-523. o. Angolul: Absolute Value and Exchangeable Value: A Rough Draft. 1823.

RiCARDO, D. [2017f]: Lord John Russell indítványa a parlament reformjára. Megjelent: Ricardo [2017a] 524-529. o. Angolul: Lord John Russell's Motion for a Reform of Parliament. 1823.

RICARDO, D. [2017g]: Az ipari munkások bére. Megjelent: Ricardo [2017a] 530-531. o. Angolul: Wages of Manufacturers: Use of Machinery. 1823.

Robinson, J. [1974]: Reflections on the Theory of International Trade. Manchester University Press, Manchester.

Robinson, J. [1978]: Keynes and Ricardo. Journal of Post Keynesian Economics, Vol. 1. No. 1. 12-18. o. htps://doi.org/10.1080/01603477.1978.11489091.

SAmuelson, P. [2001]: A Ricardo-Sraffa paradigm comparing gains from trade in inputs and finished goods. Journal of Economic Literature, Vol. 39. No. 4. 1204-1214. o. https://doi. org/10.1257/jel.39.4.1204.

Samuelson, P. [2015]: Paul Samuelson on the history of economic analysis: Selected essays. Szerk.: Medema, S.-Waterman, A. Cambridge University Press, Cambridge-New York. Schumpeter, J. [1914]: Epochen der Dogmen- und Methodengeschichte. Mohr, Tübingen. 
Schumpeter, J. [1954]: History of Economic Analysis. Allen and Unwin, London.

SeAter, J. [1993]: Ricardian equivalence. Journal of Economic Literature, Vol. 31. No. 1. 142-190. o.

Senga, S.-Fujimoto, M.-Taвuchi, T. (szerk.) [2017]: Ricardo and international trade. Routledge, Abingdon.

Solow, R. [2010]: Stories about economics and technology. European Journal of the History of Economic Thought, Vol. 17. No. 5. 1113-1126. o. https://doi.org/10.1080/096725 67.2010.522789.

SRAFFA, P. [1951]: Introduction. Megjelent: Ricardo [1951-1973] Vol. I. XIII-LXII. o.

SRAFFA, P. [1960/1975]: Áruk termelése áruk révén. Közgazdasági és Jogi Könyvkiadó, Budapest.

Steedman, I. [1982]: Marx on Ricardo. Megjelent: Bradley, I. -Howard, M. (szerk.): Classical and Marxian Political Economy: Essays in Honour of Ronald L. Meek. Macmillan, London, 115-156. o.

Stigler, G. [1953/1965]: Sraffa's Ricardo. Megjelent: Essays in the History of Economics. University of Chicago Press, Chicago, 302-325. o.

Stigler, G. [1958/1965]: Ricardo and the 93 Per Cent Labor Theory of Value. Megjelent: Essays in the History of Economics. University of Chicago Press, Chicago, 326-342. o.

Thornton, H. [1802]: An Enquiry into the Nature and Effects of the Paper Credit of Great Britain. Hatchard, London.

Toynbee, A. [1884/1909]: Anglia gazdasági forradalma a XVIII. században. Ford. Navratil Ákos. Politzer, Budapest.

Western, C. [1822]: Second Address to the Landowners of the United Empire. Ridgway, London.

Whewell, W. [1831]: Mathematical Exposition on some of the Leading Doctrines in Mr. Ricardo’s „Principles of Political Economy and Taxation”. Cambridge.

Winch, D. [1973]: Introduction to D. Ricardo: Principles of Political Economy and Taxation. Dent, London, V-XVIII. o.

Winch, D. [2009]: Wealth and Life. Cambridge University Press, Cambridge. 